\title{
29. STRATIGRAPHY OF CRETACEOUS SEDIMENTS OF THE FALKLAND PLATEAU BASED ON PLANKTONIC FORAMINIFERS, DEEP SEA DRILLING PROJECT, LEG 71
}

\author{
Valery A. Krasheninnikov, Geological Institute of the U.S.S.R. Academy of Sciences, Moscow, U.S.S.R. \\ and \\ Ivan A. Basov, Institute of the Lithosphere of the U.S.S.R. Academy of Sciences, Moscow, U.S.S.R.
}

\begin{abstract}
Lower and Upper Cretaceous sediments of the Maurice Ewing Bank, Site 511 (black shales, mudstones, zeolitic clays, and nannofossil chalk and ooze, $361 \mathrm{~m}$ thick) are characterized by an assemblage of planktonic foraminifers of low systematic diversity, including over 50 species. Representatives of Hedbergella, Globigerinelloides, Archaeoglobigerina, Whiteinella, Rugoglobigerina, and Heterohelix are predominant; species of Ticinella, Praeglobotruncana, Globotruncana, Schackoina, and Planoglobulina associated with some interbeds occur in smaller numbers. Planktonic foraminifers enable us to subdivide the Cretaceous sediments into Barremian-Aptian, Albian, upper Cenomanian, Turonian, Coniacian-Santonian, Santonian, Campanian, and upper Campanian-Maestrichtian intervals. The Lower Cretaceous (Albian) and Upper Cretaceous (upper Cenomanian-Turonian) are separated by a distinct hiatus and unconformity. In the Upper Cretaceous section, a hiatus may be present at the top of the Campanian. The upper Cenomanian-Santonian sediments are reduced in thickness, whereas the Campanian-Maestrichtian interval is expanded. In the Barremian-Aptian black shales, planktonic foraminifers are very rare: they were deposited in shallow water under anoxic conditions. In the Albian, when sedimentation conditions became oxidizing and the depth increased to 200-400 meters, they became more common. By the end of the Upper Cretaceous, depths appear to increase to 2000 meters. In the interbeds of calcareous sediments, planktonic foraminifers are common; in interbeds of zeolitic clays they are rare or absent (dissolution facies). Alternation of these types of sediments is especially characteristic of the Coniacian-lower Campanian, testifying to abrupt CCD fluctuations. The planktonic foraminifers of the Falkland Plateau belong to the Austral Province of the Southern Hemisphere. In their systematic composition they are extremely similar to microfauna of the Boreal Province of the Northern Hemisphere.
\end{abstract}

\section{INTRODUCTION}

Neither Cretaceous planktonic foraminifers nor the geological history of the Cretaceous for the higher latitudes of the South Atlantic have been studied in detail. Most early information concerned the continental fringe of this region (southern Argentina and Chile), where Cretaceous sediments fill the Austral or Magallanes Basin (southern Patagonia, Tierra del Fuego). More data became available after DSDP Leg 36 penetrated Cretaceous sediments at Sites 327 and 330 on the eastern part of the Falkland Plateau. Hole 330 reached the Precambrian crystalline basement (Barker, Dalziel, et al., 1977).

Albian, Cenomanian, Santonian, Campanian, and Maestrichtian deposits contained representative assemblages of planktonic foraminifers that allowed Sliter (1977) to observe the Austral character of microfauna, to outline the main features of the geological history of the Falkland Plateau for the Cretaceous and to make correlations with synchronous sediments of other regions of the Southern Ocean, South America, South Africa, Australia, and New Zealand. This work was an essential contribution to our knowledge of Cretaceous sediments of the high latitudes of the Southern Hemisphere. However, coring was discontinuous, and a number of problems of Cretaceous stratigraphy and the geological history remained obscure.

\footnotetext{
${ }^{1}$ Ludwig, W. J., Krasheninnikov, V. A., et al., Init. Repts. DSDP, 71: Washington (U.S. Govt. Printing Office).
}

One of the scientific tasks of Leg 71 was a further study of Mesozoic deposits of the South Atlantic, to provide, given successful coring, the Mesozoic sedimentary sequences needed to define the paleoceanographic conditions existing during the early opening and development of the Atlantic Ocean (Ludwig, Krasheninnikov, et al., 1980). Unfortunately, unfavorable sea and weather conditions did not allow us completely to accomplish this work. Mesozoic sediments were penetrated by Site 511 only (Fig. 1), at the western margin of the Maurice Ewing Bank $\left(51^{\circ} 00.28^{\prime} \mathrm{S}, 46^{\circ} 58.30^{\prime} \mathrm{W}\right.$; water depth $2589 \mathrm{~m}$; penetration $632 \mathrm{~m}$ ). The site was continuously cored; core recovery was $61 \%$. It should be emphasized that core recovery was high for the Mesozoic section and poor only for the interval at the Cretaceous/ Paleogene boundary; this is typical of the Cenozoic section. The data on the stratigraphic subdivision of the Mesozoic sediments at Site 511 considerably supplement the results obtained from studies of Leg 36 .

\section{STRATIGRAPHY OF CRETACEOUS SEDIMENTS AT SITE 511}

Cretaceous sediments, 361 meters thick, overlie, with no evident disconformity, the black shales of the Upper Jurassic (Tithonian). A disconformity does occur within the monotonous section of black shales, but it is not expressed lithologically. However, the Jurassic/Cretaceous boundary is distinctly marked by a change of palynoassemblages (Kotova, this volume) and the remains of macrofauna-ammonites, belemnites, and pelecypods (Jeletzky, this volume). This boundary can also be 


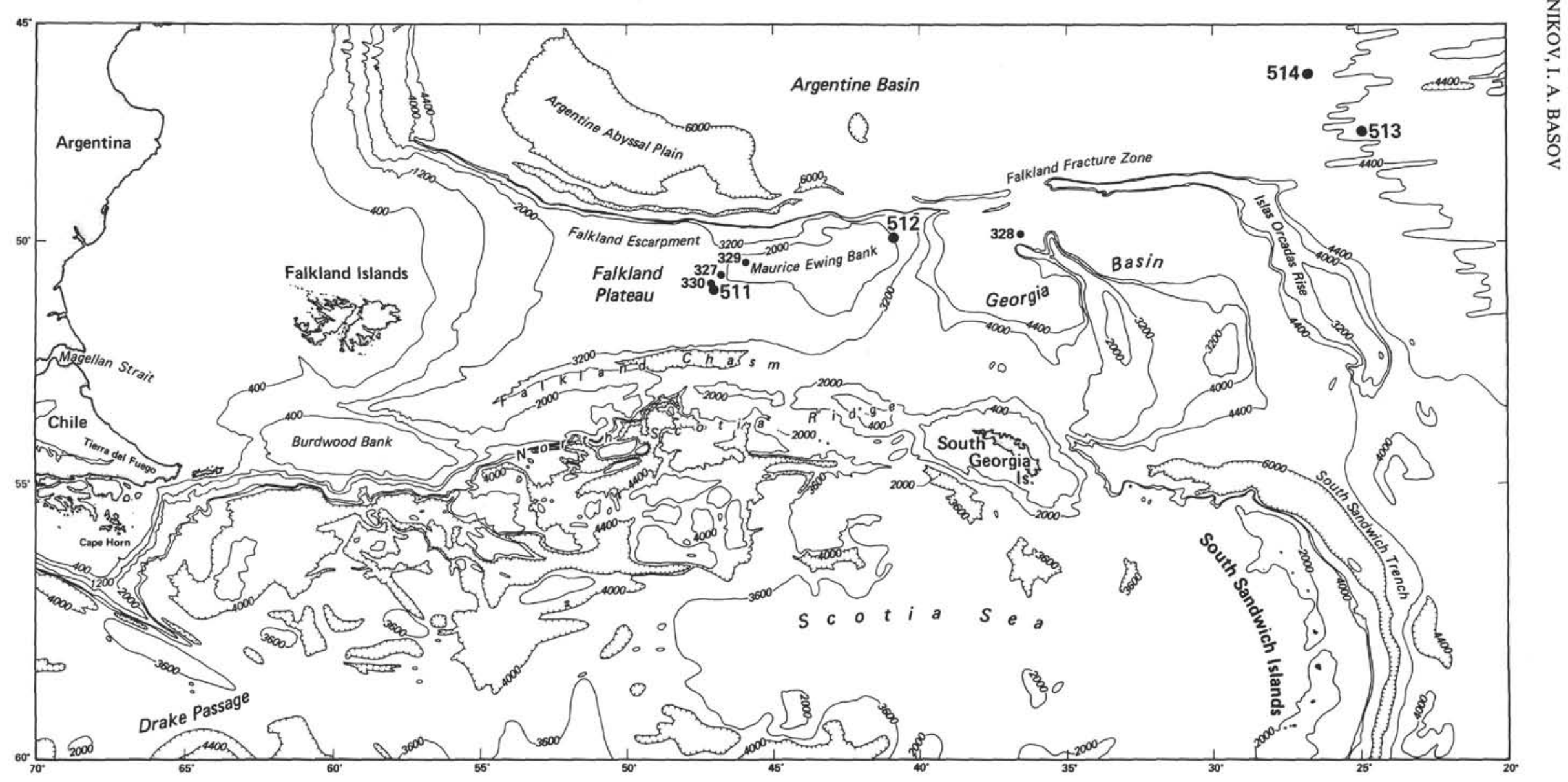

Figure 1. Leg 71 site locations. 
determined by means of planktonic foraminifers: in Upper Jurassic (Tithonian) sediments they are totally absent; in Lower Cretaceous (Barremian-Aptian) ones they are represented by rare specimens.

Cretaceous sediments include four lithological units (from bottom up):

1) Dark gray and black thinly laminated mudstones (black shales) and nannofossil claystones with a high content of organic matter and thin interbeds of zeolitic clays, hard muddy calcarenites, and clayey detrital limestones consisting of prisms of Inoceramus and fragments of other pelecypods. Pyrite is common. The sediments were formed under anoxic conditions, and benthic life is practically absent. Benthic foraminifers are extremely rare, and fragments of pelecypods were displaced from shallower underwater rises. Remains of nektonic organisms (belemnites) can be observed throughout the pile. Plankton (foraminifers and nannoplankton) are rare and occur sporadically. Thickness is $64 \mathrm{me}-$ ters, age Barremian-Aptian and earliest Albian.

2) Variegated (gray, reddish, brown, greenish) claystones, nannofossil claystones, and clayey nannofossil chalk. Some interbeds of calcareous clays are enriched with prisms of Inoceramus and fragments of Aucellina tests. Traces of intense bioturbation are frequent. The sediments were formed under oxidizing conditions and are rich in benthic, planktonic, and nektonic organisms. Thickness is 80 meters, age Albian-Turonian.

3) A sequence where calcareous gray and pale gray nannofossil and foraminiferal claystones, slightly calcareous and noncalcareous zeolitic clays, and claystones of gray, greenish gray and yellowish gray color frequently alternate. The sediments are characterized by moderate or intense bioturbation, with numerous burrows of different types (Zoophycos, Chondrites, Planolites, etc.). In calcareous interbeds there are frequent concentrations of Inoceramus prisms. Calcareous sediments contain planktonic and benthic microorganisms (foraminifers, nannoplankton); zeolitic clays (dissolution facies) are either devoid of fossils or contain rare, primitive, agglutinated foraminifers. Thickness is 203 meters, age Turonian-Campanian (and possibly early Maestrichtian).

Though the calcareous and zeolitic clays alternate throughout the sediment section, stratigraphic intervals in which one or the other type of sediment prevails can be observed. Dissolution facies are most typical of the upper Turonian, the undifferentiated Coniacian-Santonian, some intervals in the lower Campanian, and the very top of that stage. Calcareous sediments predominant in the Santonian and in the greater part of the Campanian stage.

4) White and pale gray calcareous foraminiferal and nanno-foraminiferal oozes with thin interbeds of zeolitic foraminiferal oozes, rare nodules of chert, and dispersed glauconite. Thickness is 14 meters, age later Campanian-Maestrichtian (the most probable age is early Maestrichtian).

The Cretaceous/Paleogene boundary is extremely distinct. Upper Cretaceous (probably lower Maestrichtian) nanno-foraminiferal oozes are covered by noncalcar- eous pelagic Paleogene clays (about $10 \mathrm{~m}$ thick) with recrystallized Paleocene-Eocene radiolarians. Poor core recovery and insufficient paleontological indicators in basal layers of the Paleogene make the interpretation of this boundary difficult. Nevertheless, one can hardly doubt that the Cretaceous and Paleogene are separated by a hiatus.

Planktonic foraminifers enable us to establish the following stratigraphic units in Cretaceous deposits.

\section{Barremian-Aptian}

Sediments of this age are characterized by a very poor assemblage of planktonic foraminifers consisting of $\mathrm{Hed}$ bergella infracretacea, $H$. globigerinellinoides, $H$. similis, $H$. sigali, $H$. aff. delrioensis, $H$. gorbachikae, $H$. sp., and single Globigerinelloides ferreolensis.

Foraminifers are represented by very rare specimens; many samples are devoid of microfauna (Fig. 2). The sediments are certain to be pre-Albian in age. Considering the stratigraphic ranges of the species just mentioned, the sediments should be attributed to the BarremianAptian. As the sediments are not very thick $(48 \mathrm{~m})$, they may correspond to only a part of these two stages. The interval extends from Sample 511-57, CC to Sample 511$62, \mathrm{CC}$.

The impoverishment of planktonic foraminiferal assemblages is explained, first, by shallow-water conditions. In this respect the black shales of the Falkland Plateau differ sharply from externally similar but deepwater black shales of the Angola, Cape Verde, and Morocco basins and abyssal plains and the foot of the continental slope of North America. In addition, reducing conditions of sediment formation did not favor the preservation of small, thin-walled tests of Hedbergella in surface sediments.

\footnotetext{
Albian

The Aptian/Albian boundary is drawn below the first appearance of Ticinella roberti and $T$. aff. primula in Sample 511-57-6, 11-13 cm. Albian deposits, 78 meters thick, were distinguished in the interval between Sample 511-49-5, 120-122 cm and Sample 511-57-6, 11-13 cm. The sediments of this age are characterized by rather rich assemblages of planktonic foraminifers because they were deposited in deeper water, and their formation proceeded under oxidizing conditions. From the bottom to the top of the Albian, the composition of planktonic foraminifers changes.

At the base of the Albian are observed T. roberti, $T$. aff. primula, Hedbergella infracretacea, $H$. globigerinellinoides, $H$. delrioensis, $H$. trocoidea, $H$. planispira, Globigerinelloides gyroidinaeformis (from Sample 511$55-6,34-36 \mathrm{~cm}$ to Sample 511-57-6, 11-13 cm). If we accept that the appearance of Ticinella roberti is evolutionary, the sediments should be attributed to the lower Albian, the $T$. roberti Zone.

Higher up (from Sample 511-49-6, 14-16 cm to Sample $511-55-3,34-36 \mathrm{~cm}$ ), planktonic foraminifers are usually numerous, but their species composition is not notable for its diversity $(H$. infracretacea, $H$. globigerinellinoides, $H$. delrioensis, $H$. trocoidea, $H$. planispira,
} 


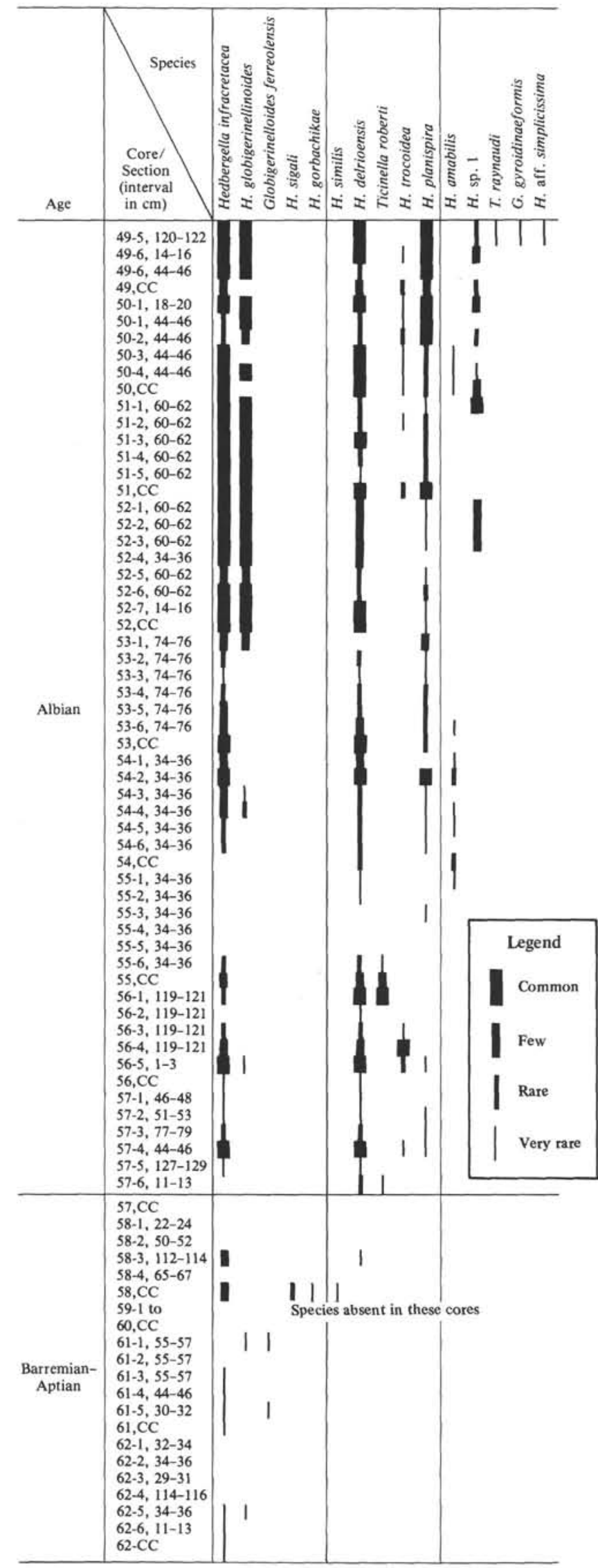

Figure 2. Distribution of planktonic foraminifers in the Albian of Hole 511. The Albian section is assumed to begin between Samples 511-49-5, 102-104 and 511-49-5, 120-122.
$H$. amabilis, $H$. brittonensis, and $H$. sp.). Species indicate an Albian age only.

In Sample 511-49-5, 120-122 cm, these species of Hedbergella and rare specimens of $T$. raynaudi with elongated last chambers were identified. These sediments appear to be upper Albian; the major part of the section was destroyed by erosion.

\section{Upper Cenomanian}

The undoubted Upper Cretaceous begins with beds containing Globigerinelloides eaglefordensis, Schackoina cenomana, Hedbergella praehelvetica, $H$. planispira, $H$. delrioensis, $H$. brittonensis, $H$. infracretacea, and $H$. portsdownensis. At the very base (Sample 51149-5, 102-104 cm), very rare specimens of Praeglobotruncana turbinata were recognized (Fig. 3). The upper part of this unit contains a scanty microfauna; very small forms of Heterohelix sp. appear here. Thickness is 16 meters (from Sample 511-48-1, 70-72 cm to Sample 511-49-5, 102-104 cm).

The presence of $P$. turbinata confines the age of these sediments to the late Cenomanian-early Turonian. Indirect evidence makes us lean toward the late Cenomanian age. The foraminiferal assemblage abounds in species of Globigerinelloides, Hedbergella, and Schackoina typical of the Cenomanian and Albian; higher up there follow deposits that are reliably Turonian.

The boundary between the Lower and Upper Cretaceous is within a lithologically monotonous section of calcareous sediments between Sample 511-49-5, 120-122 $\mathrm{cm}$ and Sample 511-49-5, 102-104 cm. Relative to paleontology the boundary is very distinct, with a considerable part of the upper Albian and probably a large part of the Cenomanian missing from the section. Thus the Lower and Upper Cretaceous are separated by a disconformity that is not lithologically evident.

\section{Turonian}

Sediments of the Turonian stage, 10 meters thick, were distinguished in the interval from Sample 511-47-1, $44-46 \mathrm{~cm}$ to Sample 511-48-1, 35-37 cm. Planktonic foraminifer assemblages make it possible to recognize the lower and upper parts.

The lower Turonian assemblage of planktonic foraminifers consists of rather numerous Praeglobotruncana aff. oraviensis (with a spinose test) accompanied by Hedbergella bornholmensis, $H$. holzli, $H$. planispira, Schackoina cenomana, Globigerinelloides asperus, Heterohelix reussi, and $H$. globulosa. Representatives of Praeglobotruncana are a significant component of the assemblage. The age of the sediments can hardly be younger than Turonian. An early Turonian age is the most probable, since double-keeled Globotruncana are absent. The interval extends from Sample 511-47,CC to Sample 511-48-1, 35-37 cm.

The upper Turonian is characterized by rare small specimens of $G$. pseudolinneiana, together with Globotruncanella inornata, Schackoina cenomana, Hedbergella aff. agalarovae, $\mathrm{H}$. bornholmensis, $\mathrm{H}$. sp., Globigerinelloides asperus, Heterohelix globulosa, and $H$. reussi. Included here under the name of Globotruncana pseudolinneiana are representatives of this genus de- 
scribed by other authors as G. lapparenti. It is quite probable that the lower/upper Turonian boundary at Site 511 corresponds to the level of evolutionary appearance of the double-keeled Globotruncana. Other species of Globotruncana are absent here. All this provided grounds to attribute these sediments to the upper Turonian. The interval extends from Sample 511-47-3, 44-46 $\mathrm{cm}$ to Sample 511-47-6, 44-46 cm.

\section{Coniacian-Santonian}

The undifferentiated Coniacian-Santonian includes sediments 28.5 meters thick in the interval from Sample 511-44-1, 44-46 cm to Sample 511-46,CC. New elements of the microfauna are Globotruncana marginata, Whiteinella baltica, Archaeoglobigerina bosquensis, and Hedbergella crassa, which occur in subordinate numbers. Ranging up from the underlying unit are $G$. pseudolinneiana, $H$. aff. agalarovae, $H$. bornholmensis, $H$. sp., Schackoina cenomana, Globigerinelloides asperus, Heterohelix globulosa, $H$. reussi, and $H$. spp. The appearance of G. marginata, Archaeoglobigerina, and Whiteinella testify to the post-Turonian age of the sediments, but it is difficult to determine their position within the Coniacian-Santonian interval.

\section{Santonian}

Sediments in the interval from Sample 511-41,CC to Sample 511-43,CC, 19 meters thick, can quite reliably be assigned to the Santonian. Here Globotruncana cretacea occurs along with $G$. pseudolinneiana and $G$. marginata. Large high- and low-conical specimens of Archaeoglobigerina bosquensis are numerous. Whiteinella baltica, Globigerinelloides asperus, Hedbergella crassa, Heterohelix globulosa, and $H$. reussi are still observed in this unit; Schackoina cenomana disappears.

Sediments of Core 42 probably belong to beds transitional to the Campanian Stage. In these sediments there appear rare Globotruncana plummerae, G. linneiana, and $G$. bulloides; there also appear very rare specimens of Globotruncana with a vaulted, very convex, spiral side that probably belong to $G$. arca (Campanian), yet may have an affinity to $G$. arcaformis Maslakova (upper Santonian-lower Campanian). The sediments of Core 42 are included at the top of the Santonian; an early Campanian age, however, cannot be excluded.

\section{Campanian}

Campanian sediments reach significant thickness $(137.5 \mathrm{~m})$; they occur in the interval from Sample 51127-1, 32-34 cm to Sample 511-41-3, 55-57 cm. Their upper boundary is conventional, as sediments of Cores 27-29 contain a very poor microfauna (dissolution facies).

The Campanian contains the richest assemblages of planktonic foraminifers, rather diverse in their species composition and with many specimens. Especially rich assemblages of planktonic foraminifers are peculiar to the middle Campanian (Cores 30-36).

In this stratigraphic subdivision Globotruncana coronata, G. globigerinoides, Archaeoglobigerina blowi, Globigerinelloides multispinatus, G. bollii, Schackoina multispinata, Heterohelix pulchra, and $H$. rumseyensis appear for the first time. Globotruncana linneiana, $G$. plummerae, and $G$. bulloides are common; in some samples $G$. arca was found. This group of Globotruncana species is very important for determining the Campanian age of the sediments. Globotruncana cretacea and $G$. marginata are still rather numerous; specimens of G. pseudolinneiana are quite sporadic and are associated with the lower Campanian. Other species include Globigerinelloides asperus, Hedbergella crassa, $H$. loetterli, Heterohelix globulosa, $H$. reussi, and $H$. sp. Archaeoglobigerina bosquensis, and Whiteinella baltica almost disappear.

The composition of planktonic foraminifers varies considerably along the section. The interbeds of zeolitic clays (dissolution facies) are certain to contain poor microfauna (Hedbergella and Heterohelix) because of secondary factors (dissolution). However, in calcareous sediments as well the composition of plankton undergoes changes. As a rule, in assemblages of planktonic foraminifers, Hedbergella and Heterohelix combined with representatives of Globigerinelloides and rare specimens of Globotruncana are dominant. Much less frequent are assemblages in which representatives of Globotruncana (G. marginata, G. cretacea, G. linneiana, G. coronata, G. globigerinoides) play an appreciable role. These variations likely reflect the primary peculiarities of the taxonomic composition of planktonic foraminiferal assemblages related to climatic fluctuations and the effect of currents.

\section{Upper Campanian-Maestrichtian}

The most abundant planktonic foraminifers were observed in calcareous oozes in the interval from Sample 511-23-1, 27-29 cm to Sample 511-26,CC (thickness, 24 $\mathrm{m})$. Their composition differs sharply from that of the underlying sediments. Widely distributed here are $\mathrm{Hed}$ bergella holmdelensis, $H$. monmouthensis, Rugoglobigerina pilula, $R$. rotundata, $R$. pustulata, Globigerinelloides impensus, and Heterohelix glabrans; Planoglobulina carseyae appears. Ranging from the underlying unit are Schackoina multispinata, Globigerinelloides multispinatus, G. asperus, Heterohelix globulosa, H. reussi, $H$. pulchra, and $H$. rumseyensis. Representatives of Globotruncana, Hedbergella crassa, Globigerinelloides bollii, Archaeoglobigerina blowi disappear completely.

Despite the abundance of planktonic foraminifers, no species with a narrow stratigraphic range appear. The age of these sediments is late Campanian-Maestrichtian. Indirect considerations favor the Maestrichtian: for instance, a thick sequence of Campanian sediments lies below the boundary, at which an abrupt change in planktonic foraminifers takes place. Calcareous nannoplankton assemblages confirm the Maestrichtian age of these oozes-the Biscutum coronum Zone (Wind and Wise, this volume).

\section{CORRELATION OF CRETACEOUS SEDIMENTS AT SITES 511, 327, AND 330}

As mentioned previously, Sites 511 (Leg 71), 327, and 330 (Leg 36) were drilled on the western part of the 


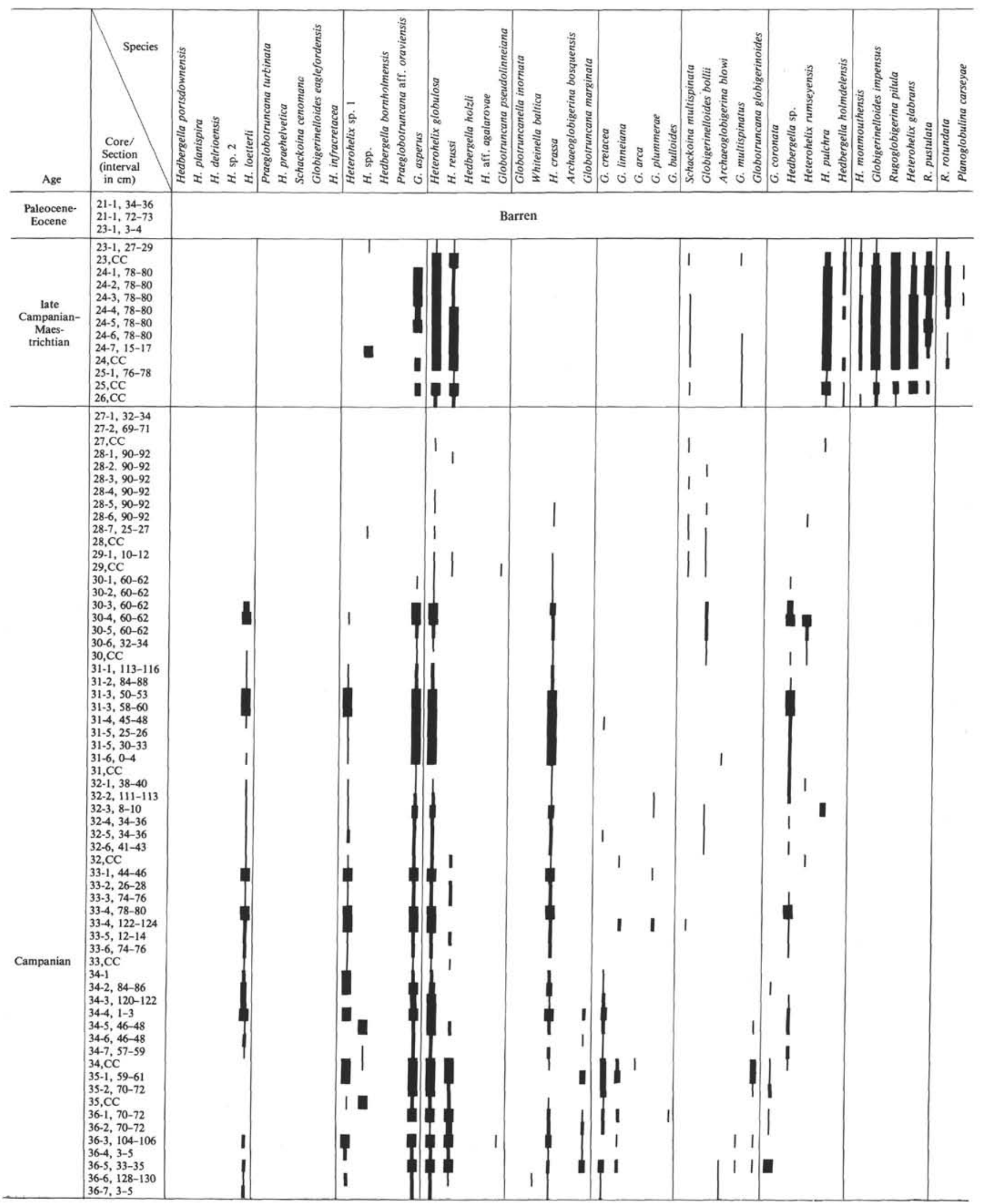

Figure 3. Distribution of planktonic foraminifers in the Upper Cretaceous of Site 511. 


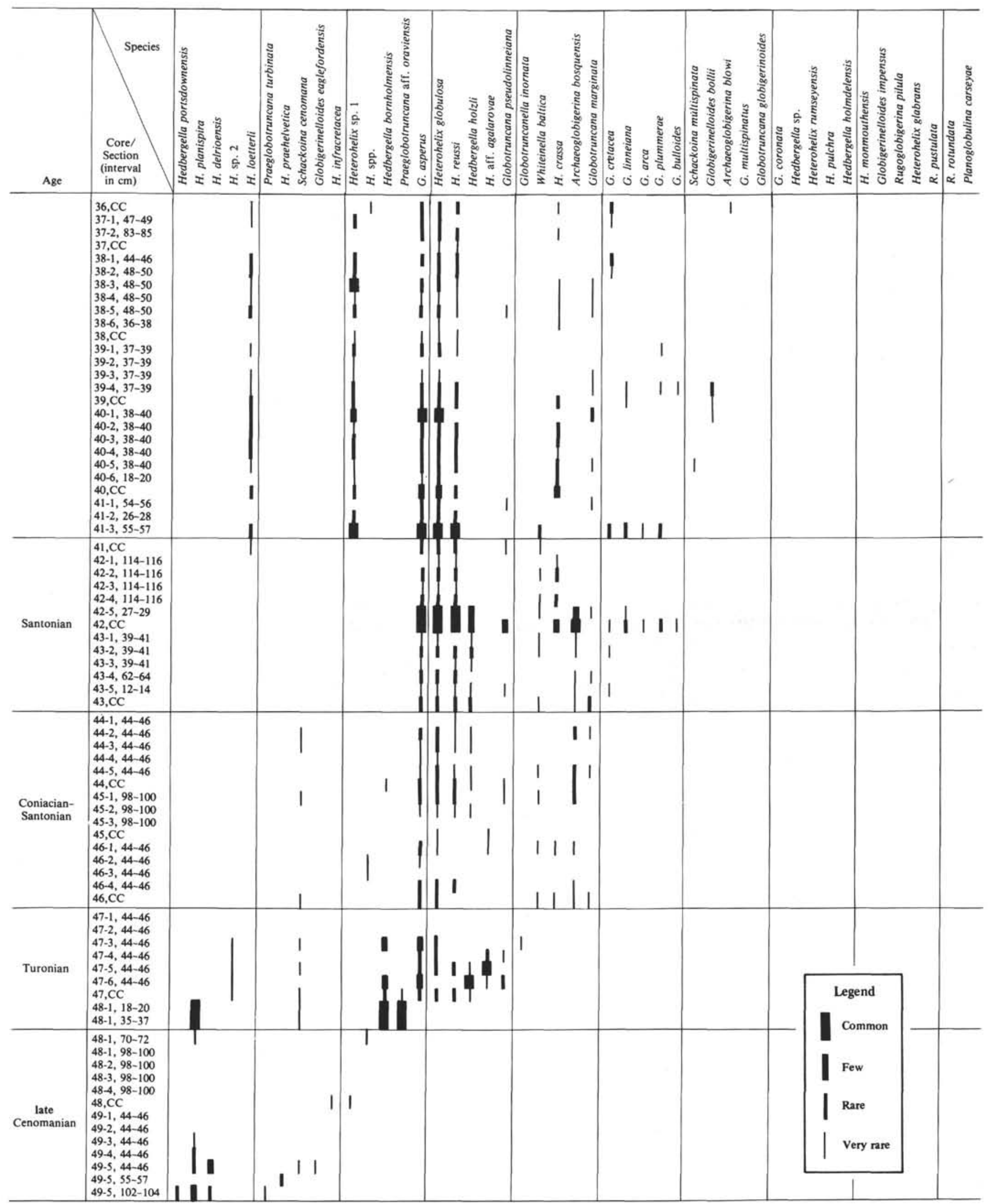

Figure 3. (Continued). 
Maurice Ewing Bank quite near each other: Site 511 is $10 \mathrm{~km}$ to the south of Site 330 and Site 327 northeastward of Site 330 at approximately the same distance. The correlation of Cretaceous sediments at these three sites enables us to understand better the stratigraphy and Cretaceous geological history within the area of the Falkland Plateau. Though Sliter (1977) rather thoroughly determined the stratigraphic subdivision of Cretaceous sediments at Sites 327 and 330, we obtained samples of sediments from these sites and studied assemblages of planktonic foraminifers, obtaining a more reliable correlation. Impoverished assemblages of planktonic foraminifers sometimes make an exact determination of sediment age difficult, but these assemblages themselves are rather characteristic and can provide direct correlations.
The Lower Cretaceous at all three sites begins with a unit of black shales containing a very poor fauna of planktonic foraminifers. At Site 511 we determined the age as Barremian-Aptian; at Sites 327 and 330, according to Sliter (1977), it is Neocomian-Aptian. We may assume that this unit everywhere overlies similar Upper Jurassic deposits (Fig. 4) with a hiatus and a disconformity that are not evident.

The lower-middle Albian at Sites 327 and 330 (Sliter, 1977) contain almost all species of planktonic foraminifers distributed in Albian sediments of Site 511, except for Ticinella roberti. At Sites 327 and 330 sediments synchronous to the basal layers of the Albian stage (with T. roberti) at Site 511 were evidently omitted because coring was discontinuous. The stratigraphic subdivisions of Sites 511, 330, and 327 are well correlated. At Sites

Site 327

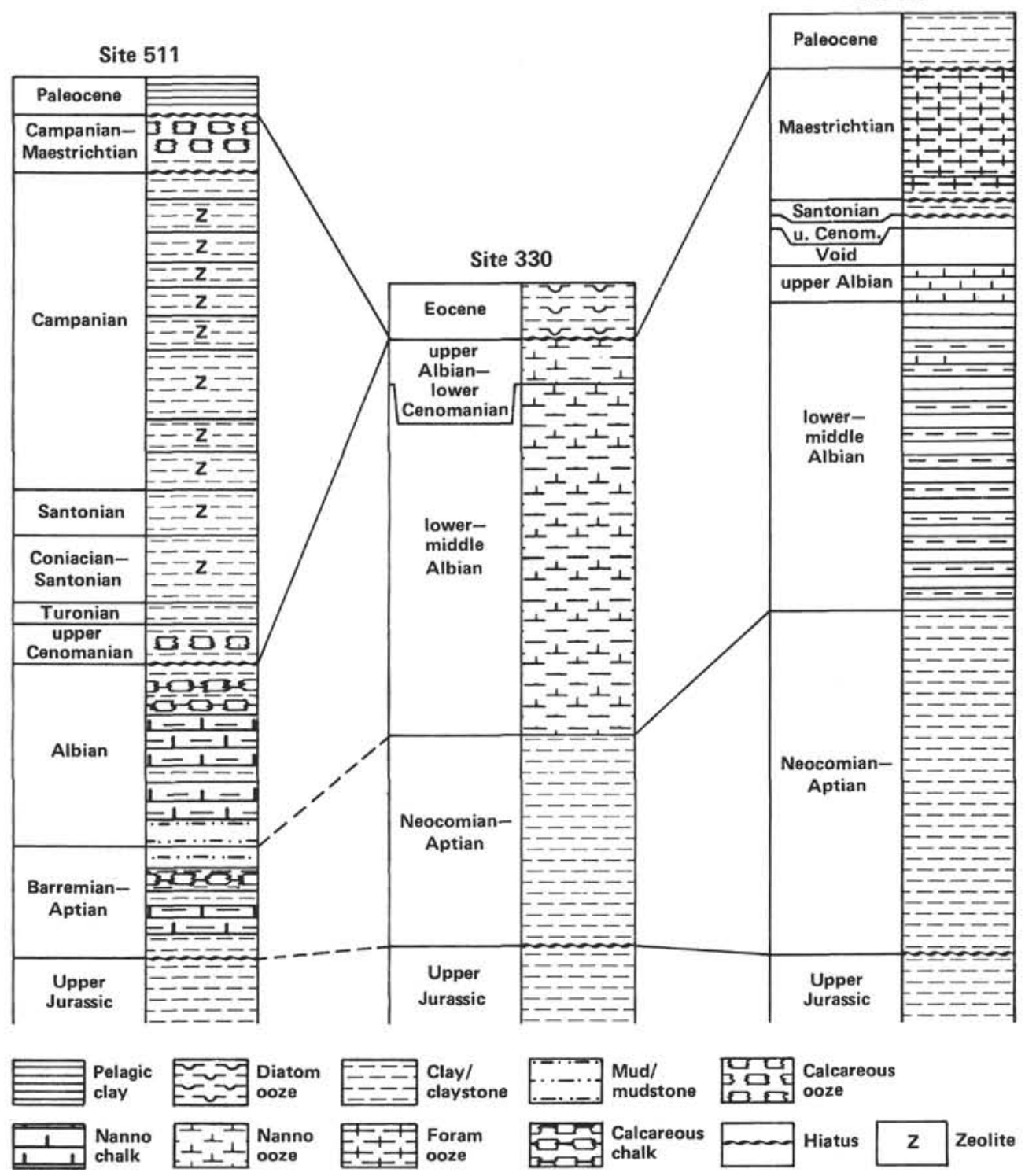

Figure 4. Correlation of Cretaceous sequences on the Falkland Plateau: 330 (Leg 36), and Sites 511 (Leg 71), 327. 
327 and 330 the Albian ends with beds containing rare Praeglobotruncana delrioensis and Schackoina cenoma$n a$; we agree with Sliter's (1977) attribution of these sediments to the upper Albian. At Site 511 is is certain that they are absent, having been destroyed by subsequent erosion. We point out again that in the uppermost sample from the Albian beds at Site 511 very rare specimens of T. raynaudi indicate a transition to the upper Albian. At Site 327142.5 meters of Albian deposits are visiblealmost twice the true thickness of the Albian sediments at Site 511. The similar decrease in thickness at Site 511 cannot be related to subsequent erosion, since the visible thickness of the upper Albian at Site 327 is only 9.5 meters (Core 15). Thus, the sedimentation rate of Albian sediments at Site 327 was almost twice as high as that at Site 511 .

At Site 327, above the upper Albian, an interval of about 20 meters was penetrated without coring. The overlying sediments (Core 14) contain Rotalipora sp., S. cenomana, $P$. delrioensis, Hedbergella planispira, $H$. delrioensis, $H$. portsdownensis, $H$. amabilis, $H$. infracretacea, and $H$. globigerinellinoides (about $2 \mathrm{~m}$ thick). Sliter (1977) recognized $R$. reicheli here. The sediments belong to the Cenomanian-if Sliter's determination is correct, to the middle Cenomanian. (We make this reservation about the correctness of his determination because the microfauna were badly preserved: we managed to find in our material only some fragments of $\mathrm{Ro}$ talipora). Cenomanian deposits with rather numerous $P$. delrioensis were also identified at Site 330 . There are no analogs to this part of the Cenomanian at Site 511, for sediments of this age were eroded.

In the same Core 14 of Site 327, the Cenomanian calcareous mudstones were replaced upward in the section by 5 meters of zeolitic clays with very rare and badly preserved planktonic foraminifers (Archaeoglobigerina bosquensis, $H$. crassa, Whiteinella baltica, Heterohelix reussi, and $H$. globulosa). As Sliter (1977) suggested, the sediments belong to the Santonian and a clear disconformity and hiatus are indicated. Our viewpoint is that these sediments are correlated with zeolitic clays and calcareous oozes of the undivided Coniacian-Santonian at Site 511. Consequently, two conclusions can be drawn: (1) Site 327 is devoid of upper Cenomanianlowermost Turonian sediments with $P$. turbinata, the lower Turonian with $P$. aff. oraviensis, and the upper Turonian with Globotruncana pseudolinneiana that are represented at Site 511; (2) at both sites in the lower part of the Upper Cretaceous we can trace a hiatus and a period of intense erosion covering in general the Cenomanian-Turonian. The magnitude of this hiatus at Sites 511 and 327 is, however, different.

At Site 327 the Coniacian-Santonian clays (dissolution facies) are overlain by nannoplanktonic and foraminiferal oozes with very rich assemblages of planktonic foraminifers (Rugoglobigerina pilula, $R$. rotundata, $R$. pustulata, Hedbergella monmouthensis, $H$. holmdelensis, Globigerinelloides impensus, Schackoina multispinata, Planoglobulina carseyae, Heterohelix glabrans, H. pulchra, etc.). Sliter (1977), who also identified rare specimens of Globotruncana arca and Globotruncanella havanensis here, attributed the sediments to the late Campanian-Maestrichtian. At Site 511 a sequence of calcareous sediments with an identical assemblage of planktonic foraminifers is analogous to these deposits. Our view of its age very nearly coincides with that of Sliter, though we opt for a purely Maestrichtian age. Two conclusions are again suggested: (1) Site 327 is completely devoid of Campanian sediments with Globotruncana arca, G. plummerae, G. linneiana, and G. corona$t a$, of Santonian sediments with $G$. marginata, G. cretacea, and abundant Archaeoglobigerina bosquensis, and of partly undifferentiated Coniacian-Santonian. These sediments, which are absent at Site 327 , are about 180 meters thick at Site 511 ; (2) somewhere at the Campanian/Maestrichtian boundary at Sites 511 and 327 there is an unconformity, but the intensity of the erosion and duration of the hiatus at these sites are different. At Site 327 the unconformity is sharp, erosion having destroyed a thick section of Santonian and Campanian sediments. A disconformity at Site 511 is not evident. It manifests itself mainly in an abrupt change in sediment facies or the aspect of the sediment. Indeed, zeolitic clays almost devoid of microfauna and conventionally placed at the top of the Campanian are overlain by calcareous nannoforaminiferal oozes that are probably Maestrichtian.

The Cenozoic at all three sites is separated from the Cretaceous by an unconformity and a hiatus. Duration of the hiatus and intensity of erosion at these three sites are however, once again different. At Site 327, the Maestrichtian is overlain by the upper Paleocene, and the Maestrichtian calcareous oozes are 57 meters thick. At Site 511, the Maestrichtian is overlain by the upper Eocene and the Maestrichtian calcareous oozes are only 24 meters thick. At Site 330, the upper Eocene rests on the lower Cenomanian-that is, the entire Upper Cretaceous virtually disappears from the section.

The correlation of Cretaceous deposits at Sites 327, 330 , and 511 enables us, first, to compile a composite section of the Cretaceous for the Falkland Plateau:

1) The late Neocomian-Aptian with very rare Hedbergella sigali, $H$. similis, $H$. infracretacea, and Globigerinelloides ferreolensis. The stratigraphy of this interval has been little known, as the microfauna is very poor.

2) The lower Albian with $T$. roberti, H. sigali, G. gyroidinaeformis, the middle Albian with various Hedbergella, and the upper Albian where rare Praeglobotruncana delrioensis, $T$. raynaudi and $S$. cenomana appear.

3) The Cenomanian, consisting of three parts: the lower part with common $P$. delrioensis and $S$. cenoma$n a$, the middle part with rare $P$. reicheli, and the upper part with rare $P$. turbinata.

4) The Turonian, composed of the lower Turonian with $P$. aff. oraviensis and $H$. bornholmensis, and the upper Turonian with Globotruncana pseudolinneiana and Globotruncanella inornata.

5) Unsubdivided Coniacian-Santonian, where Globotruncana marginata, $A$. bosquensis, $W$. baltica, and H. crassa appear. 
6) The Santonian, where the same species become standard elements of the microfauna, and where G. cretacea appears.

7) The Campanian, with various species of Globotruncana (arca, plummerae, linneiana, coronata, bulloides, and globigerinoides), S. multispinata, Globigerinelloides multispinatus.

8) The late Campanian-Maestrichtian (or Maestrichtian), an assemblage of planktonic foraminifers which consists of abundant Rugoglobigerina pilula, $R$. pustulata, $R$. rotundata, Hedbergella holmdelensis, $H$. monmouthensis, Globigerinelloides impensus, Planoglobulina carseyae, and Globotruncanella havanensis, and where representatives of Globotruncana are entirely absent.

The correlation of Cretaceous deposits at Sites 511, 327 , and 330 by planktonic foraminifers also reveals the main peculiarities of the geological development of this region. It is quite natural that the geological trend is identical in sites so close together. Lithological units change in the same succession: Barremian-Aptian black shales; calcareous claystones and nannoplanktonic chalk of the Albian-lower Turonian; zeolitic clays and nannoforaminiferal claystones of the upper Turonian-Campanian; calcareous oozes of the late Campanian-Maestrichtian (or Maestrichtian). The same disconformities and hiatuses are traced: between the Upper Jurassic and Neocomian; in the lower Upper Cretaceous (upper Cenomanian-Turonian); at the Campanian/Maestrichtian boundary; between the Upper Cretaceous and the Cenozoic.

Another factor is surprising: despite the closeness of Sites 511, 327, and 330 Cretaceous sediment sections are appreciably different, in ways that are only to a certain extent related to the primary features of sediment accumulation (at Site 327 the thickness of the Albian is twice that at Site 511). These differences are connected mostly by the character of subsequent underwater erosion, which determined the peculiarity of the sections. Thus the erosional phases of the lower Upper Cretaceous and at the Campanian/Maestrichtian boundary are expressed differently at Sites 511 and 327: (1) at Site 511 erosion first began before late Cenomanian time, whereas at Site 327 it proceeded in the late Cenomanian-Turonian; as a result, sediments of this age are missing in the section; (2) the second phase can only be assumed at Site 511 , owing to an abrupt change of facies at the Campanian/Maestrichtian boundary. At Site 327 this boundary is distinct; the Maestrichtian directly overlies the Coniacian-Santonian, and a thick sequence of Santonian-Campanian sediments is absent from the section.

The hiatus at the Mesozoic/Cenozoic boundary developed differently. At Site 327 the Cenozoic section begins with upper Paleocene sediments and erosion only slightly affected the Maestrichtian (sediment thickness is $57 \mathrm{~m}$ ); at Site 511 the upper Eocene lies at the base of the Paleogene, the Maestrichtian being moderately eroded (sediment thickness $24 \mathrm{~m}$ ); at Site 330 the Paleogene also begins with upper Eocene sediments, but erosion almost destroyed the entire Upper Cretaceous.
All of this suggests that the Maurice Ewing Bank had existed as a positive structure since the beginning of the Early Cretaceous time. As a sill, it separated the incipient Atlantic Ocean from the more southern oceanic area. The Bank appears to have been affected by unstable underwater currents that left their imprint on the character of primary sediment accumulation, and-most important-resulted in intense erosion (or nondeposition) and in hiatuses rather different in duration even in neighboring regions.

The example of the Cretaceous stratigraphy of the Maurice Ewing Bank shows how difficult it is to evaluate the main features of the stratigraphy and geological history of any underwater rise when we have at our disposal materials from only one or two sites. We have just seen that even in neighboring sites sediment sections can differ appreciably from one another. May we regard the data on stratigraphy and geological development as characteristic of the entire Maurice Ewing Bank, even more of the entire Falkland Plateau? In what way do local changes of the geological conditions of the Maurice Ewing Bank reflect subglobal alterations of the paleoenvironment? These questions await solution.

\section{MAIN FEATURES OF THE PLANKTONIC FORAMINIFERAL FAUNA OF THE FALKLAND PLATEAU}

Rather representative assemblages of planktonic foraminifers at Site 511, combined with those at Sites 327 and 330 , provide a comprehensive characterization of this group of microfauna from Cretaceous (more exactly, Albian-Upper Cretaceous) deposits of the South Atlantic high latitudes. They differ considerably from planktonic foraminifers of tropical and subtropical areas and belong to the Austral (temperate) province, though it is very difficult for us to judge the absolute values of the temperatures of the Falkland Plateau surface waters in Cretaceous time.

The most important feature of the planktonic foraminifers of the Falkland Plateau is their taxonomic impoverishment (low diversity). This manifests itself both at the generic and specific levels. Many genera of globotruncanids and heterohelicids are absent, whereas others are represented by infrequent species. Abathomphalus, Trinitella, Plummerita, Rugotruncana, Clavihedbergella, Planomalina, Pseudotextularia, Pseudoguembelina, Racemiguembelina, and Gublerina are missing. The species diversity of other genera of planktonic foraminifers is limited, some of the species being rare. The genus Ticinella is, in fact, represented by only one common species ( $T$. roberti); the two other species ( $T$. aff. primu$l a$ and $T$. raynaudi) are extremely rare. The genus Rotalipora includes one species $(R$. reicheli) that is seldom recognized. The genus Praeglobotruncana is represented by three species: two of them ( $P$. delrioensis, $P$. aff. oraviensis) are rather common, the third species ( $P$. turbinata) is extremely rare. Two species were identified within the genus Globotruncanella (G. inornata and $G$. havanensis); they are very scarce. Specimens of Planoglobulina carseyae were also very rarely observed. Nine 
species were attributed to the genus Globotruncana. Quantitatively, a "globigerine-like" $G$. cretacea is the most prevalent; G. marginata and G. coronata are common as well. In some samples G. bulloides and G. globigerinoides are rather frequent. Rare or single specimens of G. pseudolinneiana, G. linneiana, G. plummer$a e$, and $G$. arca were noted. All of them belong to double-keeled Globotruncana. Two morphological types"globigerine-like" and those with flattened subparallel spiral and ventral sides-are predominant among them. Single-keeled Globotruncana are entirely missing.

What taxa dominate in the planktonic foraminiferal assemblages? The genus Hedbergella, rather diverse, predominates in the Lower Cretaceous $(H$. infracretacea, $H$. globigerinellinoides, $H$. sigali, $H$. similis, $H$. gorbachikae, $H$. delrioensis, $H$. trocoidea, $H$. planispi$r a, H$. amabilis, $H$. aff. simplicissima, $H$. portsdownensis, and $H$. sp.). These are supplemented by very rare Globigerinelloides ferreolensis and G. gyroidinaeformis. Similarly prevalent in the Cenomanian are representatives of Hedbergella.

The situation changes in the Turonian, when, along with Hedbergella, the genera Globigerinelloides (G. asperus) and Heterohelix (H. reussi, $H$. globulosa, and $H$. sp.) play a significant role. In the Coniacian and Santonian stages the structure of paleocenosis is determined by the predominance of five genera: Hedbergella, Globigerinelloides, Heterohelix, Archaeoglobigerina, and in part Whiteinella. In the Campanian, assemblages of planktonic foraminifers are most diverse in systematic composition, but as in the previous cases, species of Hedbergella, Heterohelix, and Globigerinelloides are dominant. Archaeoglobigerina becomes scarce, and Whiteinella almost disappears. Finally, in the Maestrichtian, abundant Heterohelix (H. reussi, $H$. globulosa, $H$. pulchra, $H$. glabrans, and $H$. ramseyensis), Hedbergella $(H$. holmdelensis, $H$. monmouthensis), and Globigerinelloides (G. impensus, G. asperus, and G. multispinatus) are supplemented by no less numerous Rugoglobigerina $(R$. pilula, $R$. pustulata, and $R$. rotundata).

Thus, the basic elements of the planktonic foraminiferal assemblages are invariably representatives of $\mathrm{Hed}$ bergella, Archaeoglobigerina, Rugoglobigerina, Globigerinelloides, and Heterohelix (about 40 species). Representatives of Ticinella, Globotruncana; Globotruncanella, Rotalipora, Praeglobotruncana, Schackoina, and Planoglobulina are always subordinate in number (about 22 species).

All these planktonic foraminiferal species are known from Cretaceous deposits of tropical and subtropical areas. The species endemic to the moderate (Austral) area are almost absent or are minimal. The latter may include Globigerinelloides impensus Sliter and some species of Hedbergella described here with an open nomenclature. But this group of Upper Cretaceous planktonic foraminifers has not yet been studied thoroughly enough. We should emphasize the universal character of Cretaceous planktonic foraminifers. The specific character of the Austral microfauna of the Falkland Plateau is determined not by the presence of endemic species but by the absence of many tropical-subtropical inhabitants and by a different ratio of universal species in the foraminiferal assemblages. Species that predominate are those that in tropical-subtropical areas occur in subordinate numbers; accompanying them are rare and very rare occurrences of species that are the main constituents of the microfauna in the tropics and subtropics.

In the high latitudes, climatic fluctuations should have produced more drastic effects upon and greater contrasts in the taxonomic composition of the planktonic foraminiferal assemblages than they did in the tropics and subtropics. Peculiarities of the microfauna such as the increase in the species diversity of planktonic foraminifers, the increased numbers of the genera Ticinella, Rotalipora, and Globotruncana, and, on the whole, the appearance of their most thermophilic representatives (Globotruncana linneiana, G. arca, G. plummerae), can indicate warmer conditions in the South Atlantic.

Considering this fact, two periods of a relative increase in surface water temperatures are established on the Falkland Plateau: Albian-Cenomanian with species of Ticinella and rare Rotalipora; and the SantonianCampanian, where an assemblage of planktonic foraminifers reaches its maximum diversity, and representatives of Globotruncana, including G. linneiana, G. ar$c a$, and $G$ plummerae are common (Fig. 5). No less pronounced is the fall of temperature in the Maestrichtian: planktonic foraminifers are abundant here, considering the number of specimens, but their species diversity decreases; representatives of Globotruncana are absent. Noteworthy is the fact that within any stratigraphic subdivision (the Campanian, for instance), beds containing different planktonic foraminiferal assemblages alternate. In the Campanian zeolitic clays, which have rare Hedbergella, Heterohelix and Globigerinelloides or are devoid of plankton in general, secondary dissolution of tests because of decreases in the CCD caused impoverishment of the microfauna. There are, however, interbeds of purely calcareous oozes in which the same Hedbergella, Heterohelix, and Globigerinelloides are numerous, and species of Globotruncana are missing. We can assume temperature fluctuations on a lesser scale. These variations in the composition of the microfauna should be borne in mind when the material at our disposal is stratigraphically incomplete because of episodic coring or samples from piston cores, for instance. Otherwise, we can err in our interpretations and conclusions.

Ciesielski et al. (1977) and Ciesielski and Wise (1977) postulated that the Maurice Ewing Bank was a topographical barrier dividing two different water masses. A warm current approached the Bank from the northwest, and a cold current from the southwest. These two currents were converging eastward along the Falkland Plateau. One line of evidence for such an assumption was a sharp decrease of the Globotruncana arca specimens in the southwestern direction via the Bank. This assumption seems quite probable. Our knowledge of the Cretaceous microfauna on the southern slope of the Maurice Ewing Bank is rather comprehensive because of the drilling of Legs 36 and 71 . The material on the northern slope, however, is not sufficient (only samples from piston cores exist). Further studies on the northern slope of 


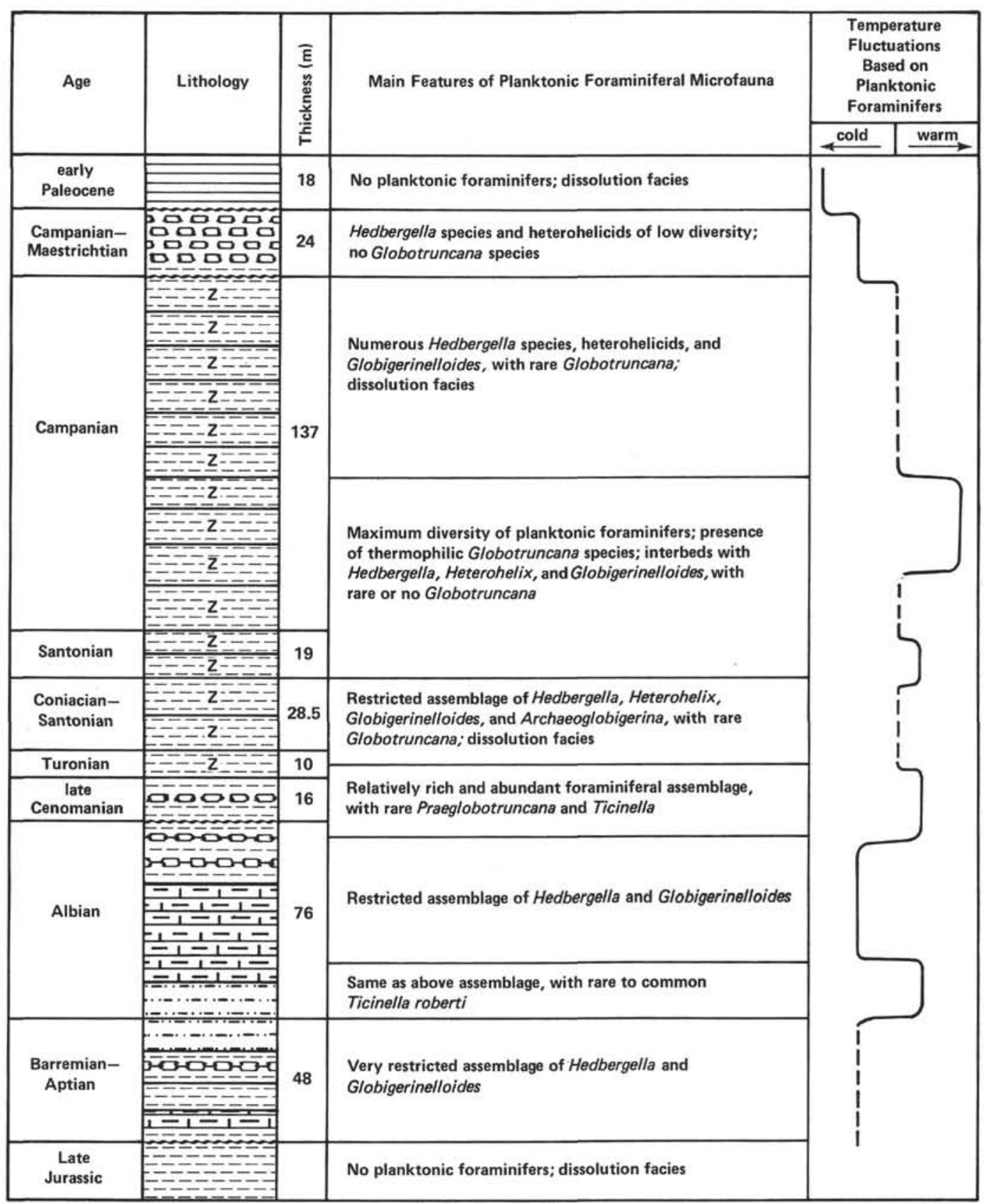

Figure 5. Characteristics of Cretaceous planktonic foraminiferal microfauna and paleoenvironmental and paleoclimatic conditions, Site 511. (For symbols, see Fig. 4).

the Falkland Plateau, we believe, will clarify the problem of Cretaceous paleogeography in this region.

Since all Cretaceous generic taxa and the vast majority of species taxa of the tropical-subtropical and Austral belts of the South Atlantic are common, it is extremely interesting to compare their stratigraphic intervals in these two areas. In this case we should certainly keep in mind not only the dating of the Cretaceous on the Falkland Plateau (ages to a certain extent are tentative), but also the relationships of various taxa.

The distribution of such genera as Heterohelix, Hedbergella, and Globigerinelloides (Barremian-Maestrichtian), as well as Schackoina (upper Albian-Maestricht- ian), is almost the same in the tropical-subtropical and Austral areas. A different situation is seen with Ticinella, Rotalipora s.l., Praeglobotruncana, Globotruncana, and Rugoglobigerina. On the Falkland Plateau Ticinella is found mostly in the lowermost Albian; in the tropical-subtropical area its complete range occupies the entire Albian. Correspondingly, Rotalipora s.1. was observed in the middle part of the Cenomanian; the entire range of this genus is upper Albian-Cenomanian. Praeglobotruncana is characteristic of the upper Albian-lower Turonian; its range is the upper Albian-Coniacian. Globotruncana was identified within the upper Turonian-Campanian; the range of this genus is lower Turoni- 
an-Maestrichtian. Rugoglobigerina was recognized in the late Campanian-Maestrichtian (possibly only Maestrichtian); its range corresponds to the Santonian-Maestrichtian. In the Cretaceous deposits of the Falkland Plateau, the stratigraphic ranges of the genera Praeglobotruncana and Globotruncana, or of Globotruncana and Rugoglobigerina do not overlap, whereas in the tropical-subtropical area the first two genera existed in the Turonian-Coniacian, and the latter two are observed together throughout the Santonian-Maestrichtian.

A number of species of planktonic foraminifers from Cretaceous sediments of the Falkland Plateau and tropical-subtropical areas are characterized by identical (or very similar) ranges. They include $H$. planispira, $H$. delrioensis, $H$. infracretacea, $H$. globigerinellinoides, $H$. portsdownensis, S. cenomana, S. multispinata, Globigerinelloides asperus, G. marginata, G. cretacea, Heterohelix globulosa, $H$. reussi, and some others. There is, however, a group of species for which ranges in the Austral and tropical-subtropical belts are appreciably different. In the tropical-subtropical area, G. globigerinoides is observed in the Coniacian-Campanian, $G$. bulloides in the Santonian-Campanian, G. plummerae in the Campanian-lower Maestrichtian, and $G$. linneiana and $G$. arca in the Campanian and Maestrichtian. On the Falkland Plateau, all of these together are characteristic of sediments of the Campanian Stage. Species such as Rugoglobigerina rotundata, $R$. pustulata, Hedbergella monmouthensis, and $H$. holmdelensis are representative of Campanian-Maestrichtian sediments of low latitudes. On the Falkland Plateau they are peculiar to sediments of the late Campanian-Maestrichtian (possibly Maestrichtian) only.

Thus times of appearance and disappearance of some genera and species in the Austral and tropical-subtropical areas coincide. These taxa are the major components of the assemblages of Cretaceous planktonic foraminifers of the Falkland Plateau. They are probably tolerant of the prevailing environmental conditions. Unfortunately, these taxa are characterized by wide stratigraphic ranges. The second group of generic and species taxa is characterized by the fact that their entire stratigraphic range (biozone) falls into tropical-subtropical areas. In the Austral belt they are distinguished by shorter stratigraphic intervals (teilzones). These taxa appear to have been to some extent stenothermic; they penetrated into the area of the Falkland Plateau during periods of warming, or together with warm-water surface currents. However, it is those genera (representatives of Ticinella, Praeglobotruncana, Rotalipora, and Globotruncana) which have, as a rule, narrow stratigraphic ranges and are the most important for Cretaceous stratigraphy.

If we recall now that planktonic foraminifers of the Austral area are devoid of many index species with a narrow stratigraphic range typical of a tropical-subtropical area, the difficulties and problems we face with the biostratigraphy of Cretaceous deposits of the Falkland Plateau become clear. Neither of the existing zonal scales of planktonic foraminifers, including the wellgrounded ones by Bolli (1966) and Hinte (1972), can be applied to Cretaceous sediments of the Falkland Plateau. It is not practicable to compile any new local scale, for impoverished assemblages of planktonic foraminifers are characterized by low stratigraphic resolution. This group of microfauna enables us to distinguish only stages here, but with two significant comments. First, in some cases we must refer to unsubdivided units (ConiacianSantonian, late Campanian-Maestrichtian). Second, the boundaries between the stages are sometimes conventional. We can rather reliably distinguish the Turonian, using Praeglobotruncana aff. oraviensis and Globotruncana pseudolinneiana; the Santonian, using abundant Archaeoglobigerina bosquensis combined with Whiteinella baltica and $G$. marginata; and the Campanian, using G. arca, G. plummerae, and G. linneiana. But where can we draw precisely the boundaries between the Turonian and Coniacian, the Santonian and Campanian, the Campanian and Maestrichtian? They are arbitrary, as one event (appearance or disappearance of any species) is not checked or delimited by other events (appearance or disappearance of other index species that are missing in the Austral belt).

True, the boundary between the Lower and Upper Cretaceous as well as that at the bottom and top of the Cretaceous system is distinct. But the boundaries between the Jurassic and Cretaceous, the Lower and Upper Cretaceous, the Cretaceous and the Paleogene coincide with disconformities and large hiatuses. Thus we do not yet know how these boundaries will be established with paleontological data where continuous sections exist.

Study of the Cretaceous stratigraphy of the Austral area leads us to a most important stratigraphic problem: What is the status of the units of the International Stratigraphic Scale (stages and zones)-regional or global? Further study of various faunistic groups from the Cretaceous of the Austral province is certain to contribute to the solution of this problem.

\section{CRETACEOUS PLANKTONIC FORAMINIFERS OF THE AUSTRAL PROVINCE}

The biogeographic peculiarities of the Cretaceous planktonic foraminifers of the Austral province are not well known. In part this is because the province is mostly covered by the Southern Ocean, and marine deposits in southern Australia and South America developed within limited areas. Deep sea drilling leads to a broader expansion of our knowledge.

The biogeographic distribution of Cretaceous planktonic foraminifers in the Southern Hemisphere was recently analyzed by Sliter (1977). This author outlines Tethyan, Transitional, and Austral provinces, differing greatly in the taxonomic composition of planktonic foraminifers and the ratio of species incorporated in their assemblages. These provinces can be considered as tropical, subtropical, and temperate; absolute temperature conditions are known only roughly, but it appears to be possible to demarcate climatic bands and reconstruct paleogeographic features, including plate movements. Referring the readers to Sliter's (1977) article, we shall here discuss biogeographical features of the microfauna reported from some localities only.

Certainly, the Cretaceous planktonic foraminiferal assemblages of the Maurice Ewing Bank most closely resemble the synchronous microfauna from the southern 
parts of Chile and Argentina-Patagonia and Tierra del Fuego (Natland et al., 1974; Malumian and Baez, 1976; Malumian and Masiuk, 1978; Malumian, 1969, 1978). The planktonic foraminiferal assemblages of this region are mainly composed of representatives of Hedbergella ( $H$. delrioensis, $H$. portsdownensis, $H$. holmdelensis, and $H$. planispira), Archaeoglobigerina (A. bosquensis, $A$. wenzeli), Rugoglobigerina (R. bulbosa, R. plana, and $R$. pilula), Whiteinella ( $W$. baltica and $W$. sp.), Globigerinelloides (G. asperus, G. gyroidinaeformis, G. caseyi, and G. multispina), and Heterohelix (H. reussi, $H$. globulosa, H. moremani). Species of double-keeled Globotruncana ( $G$. lapparenti, G. cretacea, G. marginata, G. coronata, and G. chileana) in the TuronianCampanian interval are extremely rare. The single specimen of Rugotruncana sp. is found in the Maestrichtian.

At present it is difficult to locate the boundary between the Austral and Transitional provinces in the Atlantic Ocean. Cretaceous sediments of the Walvis Ridge (Todd, 1968) and South Africa (Lambert, 1971 in Sliter, 1977) are characterized by planktonic foraminifers referred to the Transitional Province. The microfauna from Cretaceous deposits of the Rio Grande Rise (Premoli Silva and Boersma, 1977) contains even more warmwater elements. Evidently, this boundary lies to the south of the south extremity of Africa. Its position could be specified by drilling on the Agulhas Bank.

Data for the southern part of the Indian Ocean are extremely scarce. Cretaceous calcareous sediments were encountered in a core taken by Eltanin on the Kerguelen Ridge at latitude $55^{\circ} 52.78^{\prime} \mathrm{S}$ in 4304 meters water depth (Quilty, 1973). The lower part of the core, with a total thickness of 2 meters, was assigned to the late Cenomanian, its upper part to the Turonian. The upper Cenomanian assemblages consist of numerous Hedbergella amabilis, $H$. brittonensis, $H$. delrioensis, $H$. planispira, $H$. trocoidea, Clavihedbergella simplex, Globigerinelloides bentonensis, and $G$. eaglefordensis, together with rarer Schackoina cenomana, S. bicornis, Praeglobotruncana stephani, Rotalipora reicheli, $R$. multiloculatareicheli. All the listed species of Schackoina, Globigerinelloides, Clavihedbergella, and Hedbergella (except $H$. amabilis) are still present in the Turonian. They are accompanied by Globotruncana marginata, Ticinella apri$c a$, Praeglobotruncana difformis, $H$. portsdownensis, Heterohelix globulosa, and H. pulchra. Undoubtedly, these planktonic foraminiferal assemblages are very close to the Upper Cretaceous microfauna of the Falkland Plateau. Praeglobotruncana stephani can evidently be considered a synonym of $P$. turbinata. Nevertheless, the planktonic foraminifers of the Kerguelen Ridge seem warmer-water species, with more frequent representatives of Praeglobotruncana and Rotalipora. At first it seems illogical because of the higher latitudinal presentday position of the Kerguelen Ridge $\left(56^{\circ}\right)$ when compared to that of Sites 511, 330, and 327 on the Falkland Plateau $\left(51^{\circ}\right)$. But the subsided Kerguelen microcontinent presented on paleogeographical maps of the Cretaceous Indian Ocean (McKenzie and Sclater, 1971) is placed farther north, being attached to the spreading zone of the Southeast Indian Rise, and uniting with the
Broken Ridge. The ecological peculiarities of the planktonic foraminifers confirm such a reconstruction. During the Cretaceous, the Kerguelen Ridge was situated at lower paleolatitudes and differed from the Falkland Plateau in its somewhat warmer-water microfauna.

The boundary between the Austral and Transitional provinces in the Indian Ocean is quite difficult to define at the moment, because of these complicated horizontal movements of the plates. But just these ecological peculiarities of the microfauna will make it possible to outline the horizontal motions of the continental and oceanic blocks of the lithosphere.

The Cretaceous deposits of New Zealand with their impoverished assemblages of planktonic foraminifers can undoubtedly be referred to the Austral Province (Webb, 1971). The Cretaceous sediments of southern Australia-the Eucla Basin and the southern part of the Great Artesian Basin-are assigned to this province as well, although Scheibnerová (1971a, b) analyzed mainly benthic foraminifers. The taxonomic composition of the planktonic foraminifers along the west coast of Australia (the Carnarvon Basin) becomes noticeably diverse, suggesting placement in the Transitional Province (Belford, 1960; Edgell, 1957).

It can be of great interest to consider the species composition of the Albian planktonic foraminifers on the abyssal plains near the west coast of Australia (Krasheninnikov, 1974). At the Perth Abyssal Plain (Site 259) assemblages contain only abundant Hedbergella species ( $H$. infracretacea, $H$. aff. infracretacea, $H$. globigerinellinoides, $H$. amabilis, $H$. aff. delrioensis, and $H$. planispira). To the north, at the Gascoyne Abyssal Plain (Site 260), species composition is more diverse, and in addition to these planktonic foraminifers there are other species of Hedbergella $(H$. brittonensis and $H$. trocoi$d e a)$ and representatives of Globigerinelloides $(G$. bentonensis, G. eaglefordensis, G. gyroidinaeformis, G. ultramicra, G. aff. maridalensis). Species of Ticinella are completely lacking.

Again, these cold-water foraminiferal assemblages look very strange in light of modern latitudes. But on the paleogeographical maps of the Cretaceous period the Australian plate occurs in a more southerly position, and the Australian continent is attached to Antarctica. The position of the Gascoyne Abyssal Plain coincides more or less with the paleolatitudes of the Falkland Plateau; the Perth Abyssal Plain was located in even higher latitudes than the Falkland Plateau. Hence, the coldwater character of the Albian planktonic foraminifers confirms the more southerly position of this plate in the Early Cretaceous.

Some authors (for instance, Scheibnerová, 1971b, and Malumian, 1978) have already mentioned the similarity between planktonic foraminifers of the Austral Province of the Southern Hemisphere and the Boreal Province of the Northern Hemisphere. The comparison is difficult because planktonic foraminifers of the high latitudes, north and south, have been insufficiently studied. The planktonic microfauna from Cretaceous deposits of northern Poland, Germany, southern Sweden, Denmark, and England have some peculiarities in com- 
mon. They are clearly distinguished in the Cretaceous plankton of Bornholm Island (Denmark) and southern Sweden (Douglas and Rankin, 1969; Brotzen, 1936), situated between 54 and $55^{\circ} \mathrm{N}$ latitude. The CenomanianSantonian sediments are characterized by different species of Hedbergella $(H$. planispira, $H$. infracretacea, $H$. portsdownensis, $H$. bornholmensis, and $H$. aff amabilis), Globigerinelloides ehrenbergi, Whiteinella baltica, Archaeoglobigerina bosquensis, Heterohelix reussi, and $H$. pulchra; double-keeled Globotruncana (G. marginata, G. cretacea, G. coronata, and G. pseudolinneiana) are subordinate. Systematic composition and low taxonomic diversity are analogous to those of planktonic foraminifers of the Falkland Plateau. Bipolarity in the distribution of Cretaceous planktonic foraminifers is very distinctly expressed.

\section{SYSTEMATIC PALEONTOLOGY}

This chapter contains short comments on selected species of Lower and Upper Cretaceous planktonic foraminifers, touching on their morphologic peculiarities, taxonomic problems, and stratigraphic ranges. In the process of making taxonomic determinations we have faced numerous difficulties. Of course, the species found are characterized by universal geographic distribution, but at the Maurice Ewing Bank they lived near the margin of their distribution areas. These species are represented by their high-latitude geographic varieties, which differ considerably from the tropical and subtropical counterparts of these taxons. In general, dimensions of the austral varieties are smaller; keels of double-keeled Globotruncana are weakly or moderately developed; elevated keels and sutures are low, slightly ornamented and beaded; umbilici are narrower and chambers less inflated than in warm-water specimens of the same species. Very often Hedbergella species constitute the background of foraminiferal assemblages, but this genus has not been well investigated, since it occupies a subordinate position in the tropical-subtropical belts and we have some doubts concerning the correct determination of several species. Some species are described under open nomenclature, and we determined some taxons only by their generic affinity. Careful investigation of Cretaceous high-latitude planktonic foraminifers is a very important task for future research.

\section{Family SCHACKOINIDAE Genus SCHACKOINA Thalmann, 1932 Schackoina cenomana (Schacko) (Plate 1, Figs. 1-3)}

Siderolina cenomana Schacko, 1897, p. 166, pl. 4, figs. 3-5.

This species with a tiny test is readily distinguished by inflated chambers, which rapidly enlarge in size and with the peripheral ends developing into a long spine. At Site 511 it ranges from the upper Cenomanian to the Santonian and is rare.

\section{Schackoina multispinata (Cushman and Wickenden)} (Plate 1, Figs. 4-7)

Hantkenina multispinata Cushman and Wickenden, 1930, p. 40, pl. 6, figs. 4-6.

This species differs from Schackoina cenomana by having 1-2 spines on each chamber instead of 1 . Above all, chambers of $S$. multispinata are narrower in proximal parts and loosely united. The species is very sporadic in the lower part of the Campanian and constantly present in the upper Campanian-Maestrichtian of Site 511.

Family PLANOMALINIDAE

Genus GLOBIGERINELLOIDES Cushman and Ten Dam, 1948

\section{Globigerinelloides eaglefordensis (Moreman)}

(Plate 1, Figs. 8-9)

Anomalina eaglefordensis Moreman, 1927, p. 99, pl. 16, fig. 9.

The species is characterized by a small, planispiral, compressed biumbilical test with 7-8 subglobular chambers in the last whorl and a lobulate periphery. The aperture is a low interiomarginal equatorial arch bordered by a narrow lip. The species is common in the Cenomanian of North America and Europe and is also known from the Vraconian of France (Magniez-Jannin, 1975). Rarely found in the upper Cenomanian of Site 511 .

\section{Globigerinelloides gyroidinaeformis Moullade}

(Plate 1, Figs. 10-11)

“Globigerinelloides" gyroidinaeformis Moullade, 1966, p. 128, pl. 9, figs. 16-22.

The most characteristic features of this species are a pseudospiral involute test, slightly lobulate, broadly rounded periphery, very shallow umbilical deepening and a gradual enlargement of chambers as added. The species is reported from the lower and middle Albian of Europe and the Indian (Krasheninnikov, 1974) and Atlantic oceans (Pflaumann and Krasheninnikov, 1977). Rare specimens are found in the Albian of Site 511 .

\section{Globigerinelloides bollii Pessagno}

(Plate 1, Figs. 12-14)

Globigerinelloides bollii Pessagno, 1967, p. 275, pl. 62, fig. 5; pl. 81, figs, $7-8$; pl. 97, figs, $1-2 ;$ pl. 100 , fig. 3 .

The planispiral test is strongly compressed with 7-8 inflated chambers, a lobulate peripheral margin, and a broad and shallow umbilicus. Pessagno (1967) described this species from the Maestrichtian of North America. At Site 511 G. bollii is rather common in the Campanian-Maestrichtian sediments.

\section{Globigerinelloides asperus (Ehrenberg)}

(Plate 2, Figs. 1-3)

Phanerostomum asperum Ehrenberg, 1854, pl. 30, fig. 26, pl. 32, figs. 24,42 .

This species is similar to $G$. bollii, differing in that chambers are more flattened and become more rapidly taller as added. Very common in the Turonian-Maestrichtian sediments of Site 511.

\section{Globigerinelloides impensus Sliter}

(Plate 2, Figs, 4-6)

Globigerinelloides impensus Sliter, 1976, p. 541, pl. 6, figs. 1-3.

Our specimens are identical to those described by Sliter (1977) from the late Campanian at Site 327, Falkland Plateau, Leg 36. It is common in upper Campanian-Maestrichtian sediments of Site 511.

\section{Globigerinelloides multispinatus (Lalicker)}

(Plate 2, Figs. 7-9)

Biglobigerinella multispinata Lalicker, 1948, p. 624, pl. 92, figs. 1-3.

This species is readily distinguished by its small test, finely hispid subglobular chambers ( 5 in the last whorl), and double interiomarginal aperture. It is rarely present in the Campanian-Maestrichtian of Site 511 .

Family ROTALIPORIDAE

\section{Genus HEDBERGELLA Brönnimann and Brown, 1958}

Hedbergella bornholmensis Douglas and Rankin

(Plate 2, Figs. 10-12)

Hedbergella bornholmensis Douglas and Rankin, 1969, p. 193, fig. 6.

Test has a distinctly trilobate appearance, with broadly rounded periphery. Chambers subspherical, 3.5-4 in the last whorl, increasing rapidly in size. Sutures depressed; wall surface covered with small spines. Umbilicus deep and narrow; interiomarginal-umbilical aper- 
ture sometimes has a narrow lip. Morphological features of the Falkland Plateau specimens are identical to those described from the Coniacian-Santonian deposits of Bornholm Island, Denmark. Constantly present in sediments of this age at Site 511, though the number of specimens per sample is not high.

\section{Hedbergella amabilis Loeblich and Tappan}

(Plate 2, Figs. 13-15)

Hedbergella amabilis Loeblich and Tappan, 1961, p. 274, pl. 3, figs. 1-10.

Loeblich and Tappan (1961), describing the holotype of this species, noted that its test was characterized by subglobular, finely spinose chambers, 5 to (rarely) 6 in the last whorl, broad and open umblicus, and deeply depressed sutures forming a lobulate periphery. Found in the upper Cenomanian-lower Turonian of the Great Plains, North America, and later discovered in Albian deposits of many continents and oceanic basins. At Site 511 rare to common specimens of $H$. amabilis were found in Albian sediments only.

\section{Hedbergella delrioensis (Carsey)}

(Plate 3, Figs. 1-4)

Globigerina cretacea d'Orbigny var. delrioensis Carsey, 1926, p. 43.

Eicher and Worstell (1970) noted the great variability of this species. It is mostly like H. amabilis but differs from the latter by the slower rate at which chambers increase and less lobulate periphery. At Site 511 this species is common to abundant in Albian and upper Cenomanian sediments. Specimens found display visible hispidity and a slightly elevated initial whorl.

\section{Hedbergella infracretacea (Glaessner)}

(Plate 3, Figs. 5-7)

Globigerina infracretacea Glaessner, 1937, p. 28, fig. 1.

Test small, low trochospiral, compressed, with 5 inflated, slightly flattened chambers in the last whorl. Sutures radial on the ventral side and oblique on the spiral one, depressed, forming lobulate periphery. Umbilicus wide, depressed. Aperture interiomarginal, low, archlike, extending to the umbilicus. Very characteristic of the Albian, less common in the Barremian-Aptian and upper Cenomanian of Site 511.

\section{Hedbergella aff. infracretacea (Glaessner)}

(Plate 3, Figs. 16-19)

This species, with a small, very low, trochospiral compressed test, is similar to $H$. infracretacea; it differs by having 5.5-6 chambers instead of 5 in the last whorl, more compressed test, wider umbilicus, and slower increase of whorl height. It is frequent in the Albian of Site 511.

As already mentioned in the literature, $H$. infracretacea is very variable. In our material it is possible to single out at least three varieties by the peripheral margin: clearly lobulate (Plate 3, Fig. 5), lobulate (Fig. 16) and moderately lobulate (Fig. 17).

\section{Hedbergella globigerinellinoides (Subbotina) (Plate 3, Figs. 8-11)}

Globigerina globigerinellinoides Subbotina, 1949, p. 32, pl. 2, figs. $11,12$.

Test small, low trochospiral, strongly bilaterally compressed, with flattened spiral side; 6-7 chambers in the last whorl, inflated, tightly arranged, and gradually enlarging in size as added. Sutures radial, distinct, deeply depressed. Aperture interiomarginal and archlike, sometimes bordered by a narrow lip. The species is very close to Hedbergella planispira, which led some authors to consider them synonymous, but it differs from the latter in that chambers are more inflated, less tightly arranged, and lobulate in outline. Rarely present in the lower Albian at Site 511 and common in the upper Albian.

\section{Hedbergella aff. simplicissima (Magné and Sigal) (Plate 3, Figs. 12-15)}

Our specimens differ from $H$. simplicissima by their more subspherical chambers and more compact arrangement; they have 5-5.5 instead of 4-4.5 chambers in the last whorl and a less lobulate periph- ery. The outline of the species encountered is more circular. Rare specimens were found at the very top of the Albian at Site 511.

\section{Hedbergella planispira (Tappan) \\ (Plate 4, Figs. 1-6)}

Globigerina planispira Tappan, 1940, p. 122, fig. 12.

This widely distributed and long-ranging species can be easily recognized by a small, very low, trochospiral test with flat dorsal side, globular smooth chambers enlarging very gradually in size as added, and circular outline. It is rather frequent throughout the Albian-lower Turonian of Site 511.

\section{Hedbergella trocoidea (Gandolfi)}

(Plate 4, Figs. 7-9)

Anomalina lorneiana d'Orbigny var. trocoidea Gandolfi, 1942, p. 98, pl. 2, fig. 1 ; pl. 4 , figs. 2-3; pl. 13, figs. 2,5 .

This species is characterized by a low trochospiral test of medium size with 6-7 subglobular chambers enlarging gradually in size and a broadly rounded lobulate periphery. Surface is finely spinose. The species is common in the Albian and Cenomanian of different continents and oceans but at Site 511 it is characteristic only of the Cenomanian.

\section{Hedbergella brittonensis Loeblich and Tappan}

(Plate 4, Figs. 10-13)

Hedbergella brittonensis Loeblich and Tappan, 1961, p. 274, pl. 4, figs. 1-8.

This species is characterized by a high trochospiral test with a strongly convex dorsal side. The last whorl contains 6 globular chambers gradually enlarging in size, tightly arranged, and separated by radial depressed sutures. The wall is distinctly spinose. Our specimens are identical to the holotype description from the Britton Clay, Eagle Ford Group (upper Cenomanian) as well as to $H$. brittonensis from the Albian of the Indian Ocean (Krasheninnikov, 1974). At Site 511 the species was found in upper Cenomanian sediments.

\section{Hedbergella portsdownensis (Williams-Mitchell)}

(Plate 4, Figs. 14-16)

Globigerina portsdownensis Williams-Mitchell, 1948, p. 96, pl. 8, fig. 4.

Test trochospiral with convex dorsal side; 5 chambers in the final whorl, globular and gradually enlarging in size as added. Periphery is broadly rounded. Sutures are distinct, depressed, forming the lobulate peripheral outline. Aperture is a low interiomarginal arch. Test wall is almost smooth, with tiny spines. Species is common in the Cenomanian of North America and Europe. At Site 511 it is present in upper Cenomanian sediments.

Some authors consider $H$. brittonensis as a junior synonym of $H$. portsdownensis. We treat them as independent species, distinguishing the latter by its low trochospiral test, more lobulate outline, and smooth chamber surface.

\section{Hedbergella crassa (Bolli)}

(Plate 5, Figs. 1-3)

Praeglobotruncana crassa Bolli, 1959, p. 265, pl. 21, figs. 1-2.

Test small (diameter $0.2 \mathrm{~mm}$ ), very low trochospiral, with flattened spiral side and convex ventral one. Chambers oval, 5-5.5 in the last whorl, gradually enlarging in size as added. Sutures distinct, radial, widely depressed. Periphery lobulate. Aperture umbilical-extraumbilical, low, archlike. The species is present throughout the Coniacian-Campanian of Site 511.

\section{Hedbergella monmouthensis (Olsson)}

(Plate 6, Figs. 5-8)

Globorotalia monmouthensis Olsson, 1960, p. 47, pl. 9, figs. 22-24. Test small, low trochospiral, with slightly convex spiral side and more convex ventral one. Chambers globular in shape, with hispid surface, 5 in the last whorl, rapidly enlarging in size as added. Sutures radial, depressed. Periphery lobulate, rounded. Aperture a low arch with tendency to umbilical position. This species may be confused with $H$. holmdelensis but differs from the latter by its more spherical 
chambers and coarser surface. Rare specimens are constantly present in the upper Campanian-Maestrichtian of Site 511.

\section{Hedbergella sp. 1}

(Plate 5, Figs. 7-11)

Test small (diameter 0.2-0.3 mm), low trochospiral, compressed, with flattened spiral and ventral sides. Chambers enlarging rapidly in size as added, forming subquadrate lobulate outline. The last chamber sometimes occupies one-third to one-half of the last whorl. The latter usually contains 4.5 chambers, compressed, reniform, with smooth surface. Sutures radial on the ventral side and curved, depressed on the spiral side. Aperture low, archlike, with narrow lip, extending from periphery to the wide, shallow umbilicus. Specimens with 5-5.5 chambers in the last whorl and more circular lobulate outline (Figs. 9-10) evidently represent a variety of this species, which is rather frequent in the upper part of the Albian at Site 511. In the publications we examined (Subbotina, 1953; Maslakova, 1978; Magniez-Jannin, 1975; Longoria, 1974; Robazhynski et al., 1980; Hermes, 1969), we found no description and picture of this species. It is quite possibly a new one, but requires further investigation.

\section{Hedbergella sp. 2}

(Plate 5, Figs. 4-6)

Test small (diameter $0.3 \mathrm{~mm}$ ), low trochospiral, with slightly convex spiral side and more convex ventral side. Outline subquadrate, elongated, lobulate. Chambers subspherical, 4 or 4.5 in the last whorl, very rapidly enlarging in size as added, with hispid surface. Sutures distinctly radial on the spiral side and slightly curved on the ventral side, depressed. Aperture a high archlike opening in narrow umbilical area. A very characteristic species, apparently unknown in the paleontological literature. It is developed in the Turonian sediments of Site 511.

\section{Hedbergella holzli (Hagn and Zeil)}

(Plate 5, Figs. 12-14)

Globigerina holzli Hagn and Zeil, 1954, pp. 32, 50, pl. 2, fig. 8.

Test small (diameter $0.25 \mathrm{~mm}$ ), very low trochospiral, nearly planispiral, with flattened, sometimes depressed spiral side and more convex ventral side. Outline semicircular, slightly elongated, lobulate; periphery rounded. Chambers globular, 5-6 in the last whorl, gradually enlarging in size as added. Sutures distinct, radial on the ventral side and slightly curved on the dorsal side. Aperture a low arch extending from the periphery to the wide and deep umbilicus. Some specimens contain remnants of tegilla(?) or apertural flaps. Umbilical side is covered by small spines. The species is developed in Turonianlower Santonian sediments from Europe, Middle Asia, and Northern Africa (Maslakova, 1978; Vassilenko, 1961; Barr, 1972). At Site 511 this species is typical of the same stratigraphic interval and is represented by rare to common species.

The generic placement of $\mathrm{H}$. holzli is unclear. On account of the wide umbilicus and remnants of tegilla(?), this species can be attributed to the genus Whiteinella. Some authors consider $H$. holzli as a representative of the genus Rugoglobigerina.

\section{Hedbergella loetterli (Nauss)}

(Plate 6, Figs. 1-4)

Globigerina loetterli Nauss, 1947 , p. 336, pl. 49, figs. 11a-c.

Test of medium size (diameter $0.35 \mathrm{~mm}$ ), very low trochospiral, nearly planospiral, bilaterally compressed. Outline subcircular, lobulate. Chambers globular, tightly arranged, 6-7 in the last whorl, gradually enlarging in size as added. Sutures distinct, slightly curved, depressed. Test surface smooth, wall finely perforate. Aperture very low, archlike, extending from the periphery to the very wide, shallow umbilicus, covered by flap. Flaps of the preceding chambers form a pseudotegilla, which distinguishes this species from other representatives of genus Hedbergella. Our specimens are close to those described and illustrated by Douglas (1969) from the Coniacian of Northern California. It is rare to common in the Santonian-Campanian sediments of Site 511.
Genus TICINELLA Reichel, 1950

Ticinella roberti (Gandolfi)

(Plate 6, Figs. 9-12)

Anomalina roberti Gandolfi, 1942, p. 100, pl. 2, fig. 2; pl. 4, figs. 4-7, 20 ; pl. 5, fig. 1 ; pl. 13, figs. 3,6 .

This species is recognized by a large test with ovate chambers, closely arranged, 8 in the last whorl, very gradually enlarging in size as added, and by a low extraumbilical-umbilical archlike aperture. As a result of bad preservation, a secondary sutural aperture bordered by a narrow lip is observed only between the two last chambers.

This species is widely distributed in Albian sediments of different countries and of the Pacific and Atlantic oceans. At Site 511 it is present in the lower part of the Albian.

\section{Family GLOBOTRUNCANIDAE Genus GLOBOTRUNCANELLA Reiss, 1957 \\ Globotruncanella inornata (Bolli)}

(Plate 7, Figs. 1-3)

Globotruncana inornata Bolli, 1957, p. 57, pl. 13, figs. 5-6.

Test of medium size, with flattened sides. Outline is oval, lobulate. The last whorl consists of 4 chambers, oval or reniform and rapidly increasing in size as added. Keel is indistinct, as a faint imperforate band along the compressed peripheral margin, visible when the test is wet. Rare specimens in the Turonian of Site 511. In other areas of the world the species is known from the Turonian-Santonian interval.

\section{Genus WHITEINELLA Pessagno, 1967 \\ Whiteinella baltica Douglas and Rankin \\ (Plate 7, Figs. 4-9)}

Whiteinella baltica Douglas and Rankin, 1969, p. 197, figs. 9A-I.

The Falkland Plateau specimens are identical to those described by Douglas and Rankin from the Coniacian-Santonian of Bornholm Island, Denmark. The greatest similarity is with the paratypes illustrated by these authors in figures $9 \mathrm{G}, \mathrm{H}, \mathrm{I}$. Test low trochospiral, subquadrate, with strongly lobulate rounded periphery and coarsely hispid surface. Chambers inflated, 4-5 in the last whorl. Umbilicus shallow, rather small, with a flap in well-preserved tests (Fig. 6). Few but constantly present specimens of $W$. baltica were discovered in Coniacian-Santonian sediments of Site 511 and very rare specimens at the base of the Campanian.

\section{Genus PRAEGLOBOTRUNCANA Bermudez, 1952 Praeglobotruncana turbinata (Reichel)} (Plate 7, Fig. 10)

Globotruncana stephani Gandolfi var. turbinata Reichel, 1950, p. 609. Test conical, with strongly convex spiral side and flat or slightly concave ventral side. The last whorl consists of 5 narrow semicircular chambers. Surface of the spiral side is finely spinose. Keel is thin with tiny beads. Very rare specimens of $P$. turbinata were found in the upper Cenomanian of Site 511 .

\section{Praeglobotruncana aff. oraviensis Scheibnerová} (Plate 8, Figs. 8-12)

Single-keeled large test with moderately convex spiral side and concave ventral side, lobulate outline, 6-7 oval chambers in the last whorl. In the shape of the test, this species greatly resembles $P$. oraviensis from the lower Turonian of Europe, but differs considerably by strong spinosity on both sides of the test. Frequent in the lower part of the Turonian of Site 511. Deserves further investigation.

\section{Genus ARCHAEOGLOBIGERINA Pessagno, 1967 Archaeoglobigerina bosquensis Pessagno}

(Plate 8, Figs. 1-8)

Archaeoglobigerina bosquensis Pessagno, 1967, p. 316, pl. 60, figs. $7-12$.

There are two morphotypes of this species in the Site 511 material which differ in the height of trochospiral coiling (high and low trocho- 
spiral forms). Both of them have a test of medium size with globular hispid chambers, 5 in the last whorl enlarging gradually in size as added, and an open umbilicus. Our specimens are similar to those described by Douglas and Rankin (1969) from Bornholm Island. The species is constantly present throughout the Coniacian-Santonian of Site 511 and abundant in the middle part of the Santonian.

It is possible that some specimens of Whiteinella baltica from the Santonian of Site 327, illustrated in Sliter's 1977 paper, belong in reality to $A$. bosquensis.

\section{Genus GLOBOTRUNCANA Cushman, 1927 \\ Globotruncana plummerae Gandolfi \\ (Plate 7, Figs. 11-13)}

Globotruncana fornicata plummerae Gandolfi, 1955, p. 42, pl. 2, figs. 3-4.

Characteristic features of this species are small initial whorls, rapidly enlarging final whorl consisting of 4 chambers, and double-keeled periphery with wide intrakeeled band. Our specimens differ from warm-water forms by the almost flat, not inflated surface of the chambers and the rather small umbilicus. This species appears as rare specimens in the Campanian of Site 511.

\section{Globotruncana cretacea (d'Orbigny)}

(Plate 8, Figs. 13-15)

Globigerina cretacea d'Orbigny, 1840 , p. 34 , pl. 3, figs. 12-14.

The species is a characteristic element of the planktonic microfauna of the Falkland Plateau, Site 511, constant but represented by few specimens in Santonian-Campanian sediments. Its morphological features are similar to those of specimens described from Upper Cretaceous deposits of Europe and North America (Douglas and Rankin, 1969; Douglas and Sliter, 1966; Douglas, 1969, etc.) Two keels are extremely faint but clearly seen when test is wet. Surface with tiny pustules to hispid. Well-preserved specimens show infralaminal accessory apertures (Fig. 14).

\section{Globotruncana pseudolinneiana Pessagno}

(Plate 9, Figs. 1-3)

Globotruncana pseudolinneiana Pessagno, 1967, p. 310, pl. 65, figs. 24-27, pl. 76, figs. 1-3.

Very low trochospiral test with almost flat spiral and umbilical sides, angular truncate periphery, two distinct keels, lobulate outline. The last whorl consists of 5-6 triarcuate or petaloid chambers. Sutures on the spiral side beaded. Umbilical cavity is small. We include the socalled $G$. lapparenti under this species. Specimens under study differ from their warm-water counterparts by their smaller size, thinner keels, almost nonornamental sutures on the ventral side, and smaller umbilicus. Rare specimens of $G$. pseudolinneiana were encountered in the upper Turonian of Site 511.

\section{Globotruncana linneiana (d'Orbigny)}

(Plate 9, Figs. 4-6)

Rosalina linneiana d'Orbigny, 1839, p. 101, pl. 5, figs. 10-12.

This species is distinguished from $G$. pseudolinneiana by bigger test, more numerous chambers (6-7), thicker keels, more ornamental sutures on spiral and ventral sides. Petaloid chambers gradually enlarging in size as added; therefore their arrangement is more tight and outline is weakly lobulate.

$G$. linneiana is mentioned from the Santonian-Maestrichtian of many areas of Europe and America. At Site 511 rare to few specimens were found in the Santonian-Campanian sediments.

\section{Globotruncana coronata Bolli}

$$
\text { (Plate 9, Figs. 7-9) }
$$

Globotruncana lapparenti coronata Bolli, 1944, p. 233, pl. 9, fig. 14, 15; text-fig. 1, nos. 21-22.

Test large, low trochospiral, biconvex with angular truncate periphery, two closely spaced keels, and slightly lobulate outline. Chambers 7-8 in the final whorl, petaloid on spiral side, almost flat. Sutures beaded. Umbilicus wide and deep. Surface rugose. Our specimens differ from warm-water representatives of this species by less intense ornamentation (especially on the ventral side), thinner keels, and smaller umbilicus. The stratigraphic range of $G$. coronata is considered to be mainly late Turonian-Santonian extending into the Campanian. At Site 511 rare to few specimens of this species were encountered in the lower Campanian sediments; in several samples its quantity can be estimated as common.

\section{Globotruncana marginata (Reuss)}

(Plate 9, Figs. 10-14)

Rosalina marginata Reuss, 1845, p. 36 , pl. 8, figs. 54, 74; pl. 13, fig. 68.

Test low trochospiral, biconvex, with slightly convex spiral side and flattened umbilical side, angular truncate periphery (Fig. 13) or slightly rounded (Fig. 14), wide and shallow umbilicus. Chambers 6-7 in the last whorl, petaloid and almost flat on the spiral side, spherical and inflated on the ventral side. Keels are thin. Sutures are clearly beaded only on the spiral side. Surface is pustulose and outline lobulate.

After G. cretacea, this species is the most common among globotruncanids for the Upper Cretaceous of the Falkland Plateau. Rare to few specimens of $G$. marginata were encountered in the ConiacianCampanian sediments of Site 511 .

\section{Globotruncana arca (Cushman)}

(Plate 10, Figs. 1-3)

Pulvinulina arca Cushman, 1926, p. 23, pl. 3, figs. 1a-c.

This species is recognized by trochospiral double-keeled asymmetrically biconvex test with more convex spiral side, less convex ventral one, and wide depressed umbilicus. Chambers 6-7 in the last whorl, petaloid on the spiral side. Surface pustulose.

$G$. arca is a well-known species from the Campanian-Maestrichtian of the tropical/subtropical areas. Our specimens are distinguished by definitely weaker keels, poor ornamentation of sutures (especially on the ventral side), and smaller umbilicus. Very rare specimens were encountered at the base of the Campanian at Site 511 .

\section{Globotruncana bulloides Vogler}

(Plate 10, Figs. 4-9)

Globotruncana bulloides Vogler, 1941 in Maslakova, 1978, p. 87, pl. 17, fig. 3.

Test middle-sized, flattened, with slightly convex spiral side and flat umbilical side, lobulate outline, broad and deep umbilicus and pustulose surface. The last whorl contains 5-6 chambers, petaloid on the spiral side and oval on the ventral side. Two keels are distinct and separated by a broad perforated band. Septal sutures and elevated rims around umbilicus are well developed and beaded.

This species has been recognized in the Santonian-Campanian of Europe, America, and Australia. At Site 511 rare specimens of G. bulloides were found in Santonian and lower Campanian sediments.

\section{Globotruncana globigerinoides Brotzen}

(Plate 11, Figs. 1, 2)

Globotruncana globigerinoides Brotzen, 1936, p. 177, pl. 12, figs. $3 \mathrm{a}-\mathrm{c}, \mathrm{pl} .13$, fig. 3 .

This species resembles $G$. cretacea (d'Orbigny) and some authors (e.g., Douglas and Rankin, 1969) consider the former as a synonym of the latter. From our point of view, G. globigerinoides is distinguished by strongly inflated spherical chambers, 5-6 in the last whorl. The peripheral margin is more angular, truncated at the beginning of the final whorl; it is almost rounded in the last chambers. Never-the-less, a very thin double keel can be traced along the whole whorl (especially when a test is wet). Few specimens in the middle part of the Campanian at Site 511.

\section{Genus RUGOGLOBIGERINA Brönnimann, 1952 Rugoglobigerina pustulata Brönnimann (Plate 10, Figs. 10-13)}

Rugoglobigerina reicheli pustulata Brönnimann, 1952, p. 20, pl. 2, figs. 7-9; text-figs. $6 \mathrm{a}-\mathrm{m}, 7 \mathrm{a}-\mathrm{i}$.

This species is distinguished by its small low trochospiral test with 5-6 subglobular chambers in the last whorl and roughly pustulated surface. Umbilical aperture is covered by well-developed tegilla. It is common in the upper Campanian-Maestrichtian of Site 511. This species was illustrated by Sliter (1977) from the Maestrichtian sediments of neighboring Site 327 . 


\section{Rugoglobigerina pilula Belford}

(Plate 11, Figs. 3-6)

Rugoglobigerina pilula Belford, 1960, p. 92, pl. 25, figs. 7-13; textfig. 6.

Our specimens are close to those described by Belford (1960) from the Santonian and Campanian of Australia as well as to Sliter's (1977) specimens. They differ from $R$. pustulata by a more convex spiral side, more inflated chambers, comparatively loose arrangement, and less pronounced pustulose ornamentation. Common in the upper Campanian-Maestrichtian sediments of Site 511.

\section{Rugoglobigerina rotundata Brönnimann}

(Plate 11, Figs. 7-11)

Rugoglobigerina rugosa rotundata Brönnimann, 1952, pp. 34-36, pl. 4, figs. 7-9; text-figs. 15: a-c, d-f, 16: a-c.

This species differs from co-occurring $R$. pustulata and $R$, pilula by its larger, more globular test with somewhat higher trochospiral coiling, wider umbilicus, and larger aperture. It is frequently present in the upper Campanian-Maestrichtian of Site 511. Described and illustrated by Sliter (1977) from the Maestrichtian of Site 327

\section{Family HETEROHELICIDAE}

Genus PLANOGLOBULINA Cushman, 1927

Planoglobulina carseyae (Plummer)

(Plate 11, Figs. 12, 13)

Ventilabrella carseyae Plummer, 1931, p. 178, pl. 9, figs. 7-10.

This species, widely distributed in tropical-subtropical areas, is easily recognized by its flattened tapering test with chambers arranged biserially in the initial part and multiserially in adult specimens. It is rarely present in the Maestrichtian of Site 511. Described and illustrated by Sliter (1977) from the upper Campanian-Maestrichtian of Site 327.

\section{Genus HETEROHELIX Ehrenberg, 1843 \\ Heterohelix globulosa (Ehrenberg)}

(Plate 12, Figs. 13-15)

Textularia globulosa Ehrenberg, 1840 , p. 135 , pl. 4 , figs. $1 \beta, 2 \beta, 4 \beta$, $5 \beta, 7 \beta, 8 \beta$.

This long-ranged species is widely distributed and is recognized by globular chambers gradually enlarging in size as added and lobulate periphery. It is common throughout the Turonian-Maestrichtian of Site 511. Sliter (1977) found this species in the Santonian-Maestrichtian of Site 327.

\section{Heterohelix reussi (Cushman)}

(Plate 12, Figs. 1-3)

Guembelina reussi Cushman, 1938, p. 11, pl. 2, figs. 6-9.

This species differs from $H$. globulosa by broad wedgelike test with spherical, rapidly enlarging chambers covered by longitudinal, thin costae. It is common to abundant in the Santonian-Maestrichtian and rare to few in the Turonian-Coniacian of Site 511. Sliter (1977) restricted its range to within the Santonian at Site 327.

\section{Heterohelix glabrans (Cushman)}

(Plate 12, Figs. 9, 10)

Guembelina glabrans Cushman, 1946, p. 109, pl. 46, figs. 17-18.

This species is distinguished by a strongly compressed test, biserially arranged chambers gradually enlarging in size as added, and subacute slightly lobulate periphery. It is widely distributed in the Maestrichtian of North America, Europe, and many DSDP sites. Common in the Maestrichtian of Site 511. According to Sliter (1977), it appears in the late Campanian and is common in the Maestrichtian of Site 327.

\section{Heterohelix pulchra (Brotzen)}

(Plate 12, Figs. 6-8)

Guembelina pulchra Brotzen, 1936, p. 121, pl. 9, figs. 2-3.

Specimens referred here to $H$. pulchra differ from other species of the genus Heterohelix encountered in the Upper Cretaceous of Site 511 in having an elongated, biserial, compressed, moderately widening test, with low compressed chambers enlarging in size as added and limbate depressed sutures. The species is widely distributed throughout the world from the Campanian to the Maestrichtian. Our specimens are found in the Campanian-Maestrichtian of Site 511; the same stratigraphic interval was given by Sliter (1977) at Site 327.

\section{Heterohelix rumseyensis Douglas}

(Plate 12, Figs. 4-5)

Heterohelix rumseyensis Douglas, 1969, p. 159, pl. 11, figs. 9-11.

Test biserial, in the initial part rapidly tapering, in the adult portion gently tapering, almost with parallel outlines. Chambers subglobular, wider than high, separated by straight, depressed sutures, giving the lobulate outline. Wall is covered by faint longitudinal costae. Morphological patterns of our specimens are identical to those of the holotype and paratypes from the Santonian-Campanian of California (Douglas, 1969). This author found $H$. rumseyensis also in the Campanian of Alaska. Rare specimens in the upper part of the Campanian, Site 511.

Heterohelix sp. 1

(Plate 12, Figs. 11-12)

Test small (length $0.2 \mathrm{~mm}$ ), gradually tapering, laterally compressed. Chambers oval, separated by depressed, strongly oblique sutures which give the test a braidlike appearance. Surface is covered by rare tiny pustules. Common in the Campanian sediments of Site 511 .

\section{ACKNOWLEDGMENTS}

The authors wish to express their thanks to the Deep Sea Drilling Project for its kind invitation to participate in Leg 71, to Prof. N. I. Maslakova, Moscow State University, for her many valuable suggestions about the taxonomy of Cretaceous planktonic foraminifers, and to Dr. T. P. Bondareva, Geological Institute of the U.S.S.R. Academy of Sciences, for reviewing the manuscript. We are grateful to N. D. Serebrjanikova (Geological Institute of the U.S.S.R. Academy of Sciences), who took all micrographs.

\section{REFERENCES}

Barker, P. F., Dalziel, I. W. D., et al., 1977. Init. Repts. DSDP, 36: Washington (U.S. Govt. Printing Office).

Barr, F. T., 1972. Cretaceous biostratigraphy and planktonic foraminifera of Libya. Micropaleontology, 18(no. 1):1-46.

Belford, D. J., 1960. Upper Cretaceous Foraminifera from the Toolonga Calcilutite and Gingin Chalk, Western Australia. Bur. Min. Res. Geol. Geophys. Bull., No. 57.

Bermudez, P. J., 1952. Estudio sistematico de los Foraminiferos Rotaliformes. Min. Minas Hidrocarburos, Bol. Geol., Vol. 2(no. 4).

Bolli, H. M., 1944. Zur Stratigraphie der Oberen Kreide in den hoheren helvetischen Decken. Eclogae Geol. Helv., 37(no. 2).

1957. The genera Praeglobotruncana, Rotalipora, Globotruncana and Abathomphalus in the Upper Cretaceous of Trinidad. U.S. Nat. Mus. Bull., No. 215.

1959. Planktonic Foraminifera from the Cretaceous of Trinidad, Bull. Am. Paleontol, 39(no. 179).

1966. Zonation of Cretaceous to Pliocene marine sediments based on planktonic Foraminifera. Bol. Inform. Asoc. Venez. Geol. Min. Petrol., 9(no. 1).

Brönnimann, P., 1952. Globigerinidae from the Upper Cretaceous (Cenomanian-Maastrichtian) of Trinidad. Bull. Am. Paleontol., 34(no, 140).

Brönnimann, P., and Brown, N., 1958. Hedbergella: a new name for a Cretaceous planktonic foraminiferal genus. J. Washington Acad. Sci., 48(No. 1).

Brötzen, F., 1936. Foraminiferen aus dem Schwedischen untersten Senon von Eriksdal in Schonen. Sveriges Geol. Unders. Arsbok, 30(no. 3), Ser. C, No. 396.

Carsey, D., 1926. Foraminifera of the Cretaceous of Central Texas. Univ. Texas Bull., No. 2612.

Ciesielski, P. F., Sliter, W. V., Wind, F. H., and Wise, S. W., 1977. Paleo-environmental analysis and correlation of a Cretaceous Islas Orcadas core from the Falkland Plateau, Southwest Atlantic. Mar. Micropaleontol., 2:27-34.

Ciesielski, P. F., and Wise, S. W., 1977. Geologic history of the Maurice Ewing Bank (Southwest Atlantic sector of the Southern Ocean) based on piston and drill cores. Mar. Geol., 25:175-207. 
Cushman, J., 1926. Some Foraminifera from the Mendez Shale of Eastern Mexico. Contr. Cushman Lab. Foram. Res., 2(pt. 1):16-26.

1927. Some characteristic Mexican fossil Foraminifera. $J$. Paleontol., 1(no. 2).

1938. Some new species of Rotaliform Foraminifera from the American Cretaceous. Contr. Cushman Lab. Foram. Res., 14(pt. 3).

1946. Upper Cretaceous Foraminifera of the Gulf Coastal Region of the United States and Adjacent Area. U.S. Geol. Surv. Prof. Paper 206.

Cushman, J., and Wickenden, R. T., 1930. The development of Hantkenina in the Cretaceous with a description of a new species. Contr. Cushman Lab. Foram. Res., 6(pt. 2).

d'Orbigny, A. D., 1839. Foraminifères. In de la Sagra, R. (Ed.), Histoire physique, Politique et Naturelle de l'ile de Cuba: Paris (Bertrand).

1840. Memoire sur les Foraminifères de la craie blanche du bassin de Paris. Mem. Soc. géol. France, 4(pt. 1).

Douglas, R. G., 1969. Upper Cretaceous planktonic foraminifera in Northern California. Part I-Systematics. Micropaleontology, 15(no. 2):151-209.

Douglas, R. G., and Rankin, C., 1969. Cretaceous Planktonic foraminifera from Bornholm and their zoogeographic significance. Lethaia, 2:185-217.

Douglas, R. G., and Sliter, W. V., 1966. Regional distribution of some Cretaceous Rotaliporidae and Globotruncanidae (Foraminierida) within North America. Tulane Stud. Geol., 4(no. 3):89-131.

Edgell, H. S., 1957. The genus Globotruncana in north-west Australia. Micropaleontology, 3(no. 2):101-126.

Ehrenberg, C. G., 1840. Über die Bildung der Kreidefelsen und des Kreidemergeln durch unsichtbare Organismen. K. Akad. Wiss. Berlin, Phys. Abh., Jahr 1838.

1854. Microgeologie: Leipzig (L. Voss).

Eicher, D. L., and Worstell, P., 1970. Cenomanian and Turonian foraminifera from the Great Plains, United States. Micropaleontology, 16(no. 3):269-324.

Gandolfi, R., 1942. Richerche micropaleontologiche e stratigraphiche sulla Scaglia e sul flysh Cretacici dei Dintori di Balerna (Canton Ticino), Riv, Ital. Paleontol, Ann, 48, Mem. 4.

1955. A Globotruncana fauna from the Pecan Gap chalk of Texas. Micropaleontology, 1(No. 3).

Glaessner, M. F., 1937. Planktonforaminiferen aus der Kreide und dem Eozän und ihre stratigraphische Bedeutung. Moscow Univ., Lab. Paleont., Stud. Micropaleont., 1(pt. 1).

Hagn, H., and Zeil, W., 1954. Globotruncanen aus dem Ober-Cenoman und Unter-Turon der Bayerischen Alpen: Eclogae Geol. Helv. 47(no. 1).

Hermes, J. J., 1969. Late Albian foraminifera from the Subbetic of southern Spain. Geol. Mijnbouw, 48(1):35-66.

Krasheninnikov, V. A., 1974. Cretaceous and Paleogene planktonic Foraminifera, Leg 27 of the Deep Sea Drilling Project. In Veevers, J. J., Heirtzler, J. R., et al., Init. Repts. DSDP, 27: Washington (U.S. Govt. Printing Office), 663-681.

Lalicker, C. G., 1948. A new genus of Foraminifera from the Upper Cretaceous. J. Paleontol., 22.

Lambert, G., 1971. A study of the Cretaceous foraminifers of northern Zululand, South Africa [N.Sc. thesis]

Loeblich, A. R., Tappan, H., 1961. Cretaceous planktonic foraminifera: Part I. Cenomanian. Micropaleontol., 16(no. 3):269-324.

Longoria, J. F., 1974. Stratigraphic, morphologic and taxonomic studies of Aptian planktonic Foraminifera. Rev. Espan. Micropaleontol., no. extraord.

Ludwig, W. J., Krasheninnikov, V. A., et al., 1980. Tertiary and Cretaceous paleoenvironment in the Southwest Atlantic Ocean: Preliminary results of Deep Sea Drilling Project Leg 71. Geol. Soc. Am. Bull., Part I, 91:655-664.

McKenzie, D., and Sclater, J. G, 1971. The evolution of the Indian Ocean since the Late Cretaceous. Geophys. J. R. Astron. Soc., 25:437-528.

Magniez-Jannin, F., 1975. Les foraminifères de l'Albien de l'Aube: Paléontologie, stratigraphie, ecologie: Paris (C.N.R.S.).

Malumian, N., 1969. Foraminiferos del Cretácico superior y Terciario del Subsuelo de la Provincia Santa Cruz, Argentina. Ameghiniana, 5(6):191-277.
1978. Aspectos paleoecologicos de los foraminiferos del Cretacico de la Cuenca Austral. Ameghiniana, 15(no. 1-2):149-160.

Malumian, N., and Baez, A. M., 1976. Outline of Cretaceous stratigraphy of Argentina. Ann. Mus. Hist. Nat. Nice, 4:27.1-10.

Malumian, N., and Masiuk, V., 1978. Foraminiferos planctonicos del Cretácico de Tierra del Fuego. Rev. Geol. Asoc. Argentina, 33(1): $36-51$.

Maslakova, N. I., 1978. Globotruncanidae from the south European part of the U.S.S.R.: Moscow (Nauka). (In Russian)

Moreman, W. L., 1927. Fossil zones of the Eagle Ford of north Texas. J. Paleontol., 1(no. 1).

Moullade, M., 1966. Etude stratigraphique et micropaléontologique du Crétacé inférieur de la "Fosse vocontienne." Doc. Lab. Géol. Fac. Sci., 15:1.

Natland, M. L., Gonzalez, P. E., Canon, A. and Ernst, M., 1974. A System of Stages for Correlation of Magallanes Basin Sediments. Geol. Soc. Am. Mem. 139.

Nauss, A. W., 1947. Cretaceous microfossils of the Vermilion area, Alberta. J. Paleontol., 21(no. 4).

Olsson, R., 1960. Foraminifera of the latest Cretaceous and earliest Tertiary age in the New Jersey coastal plain. J. Paleontol., 34(no. 1).

Pessagno, E. A., 1967. Upper Cretaceous Planktonic Foraminifera from the Western Gulf Coastal Plain. Paleontol. Res. Inst., 5(no. 37).

1967. Upper Cretaceous planktonic foraminifera from the western Gulf Coastal Plain. Paleontolog. Am., 5:245-445.

Pflaumann, U., and Krasheninnikov, V. A., 1978. Early Cretaceous planktonic foraminifers from eastern North Atlantic, DSDP Leg 41. In Lancelot, Y., Seibold, E., et al., Init. Repts. DSDP, 41: Washington (U.S. Govt. Printing Office),, 539-564.

Plummer, H., 1931. Some Cretaceous Foraminifera in Texas. Univ. Texas Bull., No. 3101.

Premoli Silva, I., and Boersma, A., 1977. Cretaceous planktonic foraminifers-DSDP Leg 39 (South Atlantic). In Supko, P. R., PerchNielsen, K., et al., Init. Repts. DSDP, 39: Washington (U.S. Govt. Printing Office), 615-641.

Quilty, P., 1973. Cenomanian-Turonian and Neogene sediments from northeast of Kerguelen Ridge, Indian Ocean. J. Geol. Soc. Aust., 20(pt. 3):361-367.

Reichel, M., 1950. Observations sur les Globotruncana du gisement de la Breggia (Tessin): Eclogae Geol. Helv., 42(no. 2).

Reuss, A. E., 1845. Die Versteinerungen der böhmischen Kreideformation: Abt. 1: Stuttgart (E. Schweizerbart)

Robazhynski, F., Amedro, F., Foucher, J. C., Gaspard, D., MagniezJannin, F., Manivit, and H. et Sornay, J., 1980. Synthèse biostratigraphique de l'Aptien au Santonien do Boulonnais a partir de sept groupes paléontologiques: foraminifères, nannoplancton, dinoflagellés et macrofaunes. Rev. Micropaleontol., 22(no. 4).

Schacko, G., 1897. Beitrag über Foraminiferen aus der CenomanKreide von Moltzow in Mecklenburg. Ver. Naturg. Mecklenburg Arch, 50.

Scheibnerova, V., 1971a. Palaeoecology and palaeogeography of the Cretaceous deposits of the Great Artesian Basin (Australia). Geol. Surv. N.S.W. Rec., 13:1-48.

1971b. The Great Artesian Basin, Australia, a type area of the Austral biogeoprovince of the Southern Hemisphere, equivalent to the Boreal biogeoprovince of the Northern Hemisphere. In Farinacci, A (Ed.), Proc. II Planktonic Conf.: Rome (Edizioni Tecnoscienza), pp. 1129-1138.

Sliter, W. V., 1977. Cretaceous foraminifers from the southwestern Atlantic Ocean, Leg 36, Deep Sea Drilling Project. In Barker, P. F., Dalziel, I. W. D., et al., Init. Repts. DSDP, 36: Washington (U.S. Govt. Printing Office), 519-574.

Subbotina, N. N., 1949. Microfauna of the U.S.S.R. Petroleum Districts. Monographic Study of the Foraminiferal fauna in the Lower Cretaceous Deposits of Southern Emba District. Microfauna of the U.S.S.R. VNIGRI, Trudy, N. Ser. 2 (Pt. 5).

Tappan, H., 1940. Foraminifera from the Grayson formation of northern Texas. J. Paleontol., 14.

van Hinte, J., 1972. The Cretaceous Time Scale and Planktonic Foraminiferal Zones. Proc. Nederl. Akad. Wet., Ser. B, Vol. 75.

Williams-Mitchel, E., 1948. The zonal value of Foraminifera in the chalk of England. Proc. Geol. Assoc. London, 59(pt. 2). 

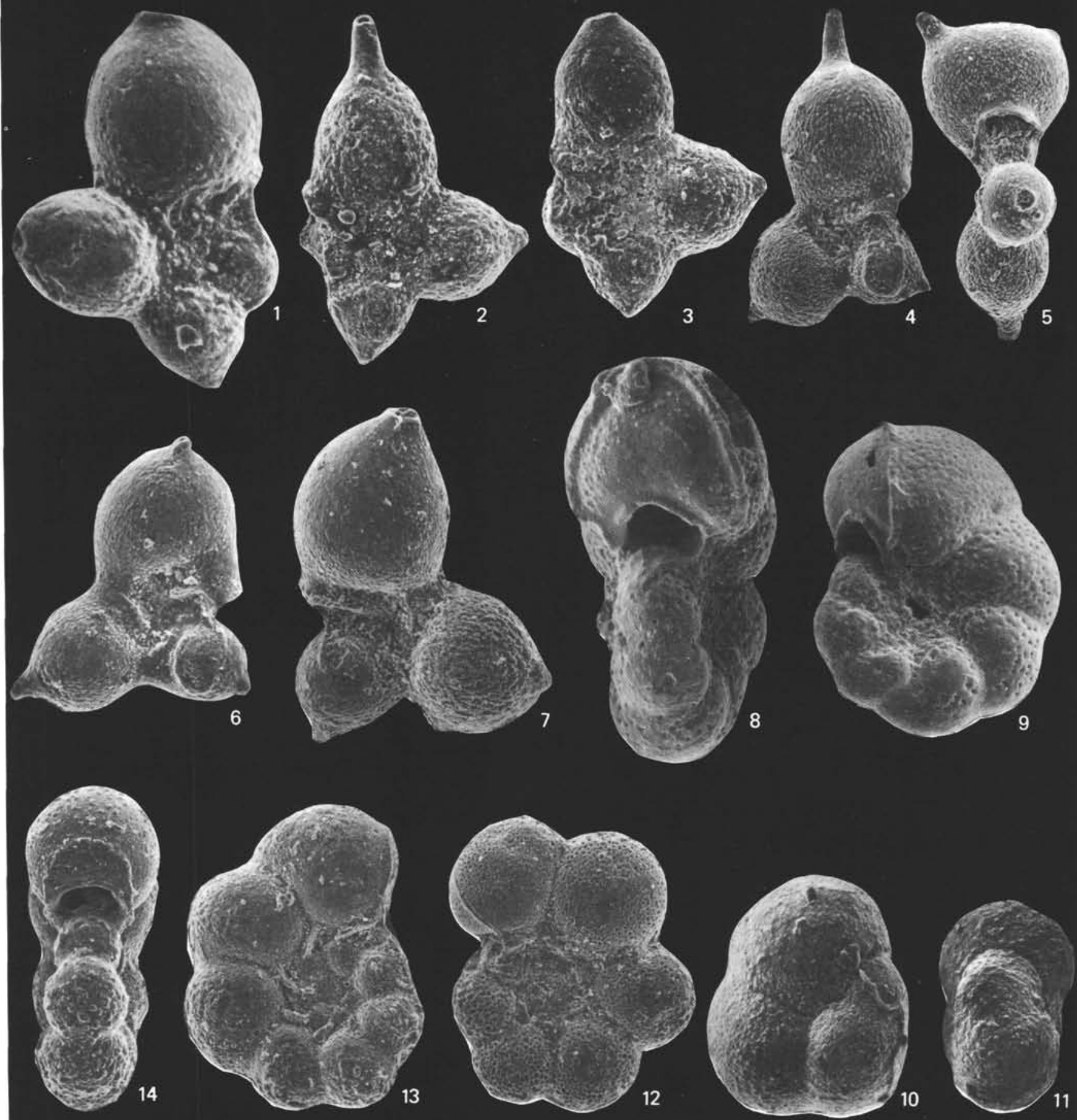

Plate 1. Cretaceous planktonic foraminifers, 1-3. Schackoina cenomana (Schacko), side views, (1) $\times 300$, Sample 511-49-5, 102-104 cm, (2-3) $\times 250$ (2, Sample 511-47-5, 44-46 cm; 3, Sample 511-46,CC). 4-7. Schackoina multispinata (Cushman and Wickenden), $\times 150,(4-5)$ Sample 511-24,CC (4, side view; 5, apertural view), (6-7) side view (6, Sample 511-24-6, 78-80 cm; 7, Sample 511-24-4, 78-80 cm). 8-9. Globigerinelloides eaglefordensis (Moremann), $\times 200$, Sample 511-49-5, 44-46 cm, (8) apertural view, (9) side view. 10-11. Globigerinelloides gyroidinaeformis Moullade, Sample 511-49-5, 120-122 cm, (10) $\times 110$, side view, (11) $\times 100$, apertural view. $12-14$. Globigerinelloides bollii Pessagno, Sample $511-24, \mathrm{CC},(12-13) \times 140$, side view, $(14) \times 150$, apertural view. 


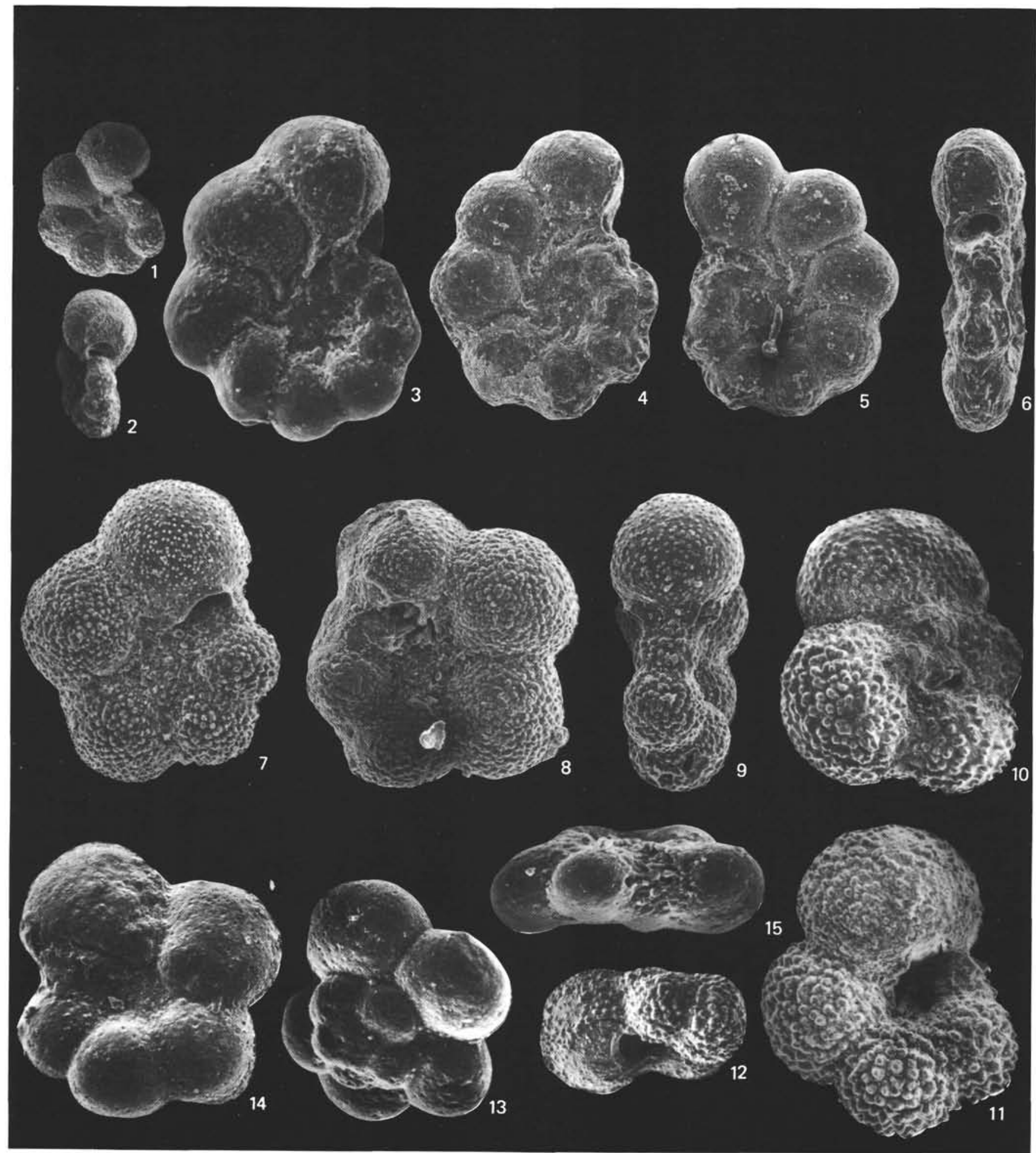

Plate 2. Cretaceous planktonic foraminifers. 1-3. Globigerinelloides asperus (Ehrenberg) $(1-2) \times 100$ Sample $511-42$, CC (1, side view; 2 , apertural view). (3) $\times 250$, side view, Sample 511-45-1, 98-100 cm. 4-6. Globigerinelloides impensus Sliter, Sample 511-24,CC (4-5) side view (4, $\times 140 ; 5 \times 120)(6) \times 140$, apertural view. $7-9$. Globigerinelloides multispinatus (Lalicker) $\times 170$, Sample $511-24-5,78-80 \mathrm{~cm},(7-8)$ side view, (9) apertural view. 10-12. Hedbergella bornholmensis Douglas and Rankin (10-11) $\times 200$, Sample 511-48-1, 35-37 cm (10, spiral view; 11, ventral view), (12) $\times 140$, peripheral view, Sample 511-47-6, 44-46 cm. 13-15. Hedbergella amabilis Loeblich and Tappan, $\times 300$, Sample 511-54$2,34-36 \mathrm{~cm}$ (13) spiral view, (14) ventral view, (15) peripheral view. 


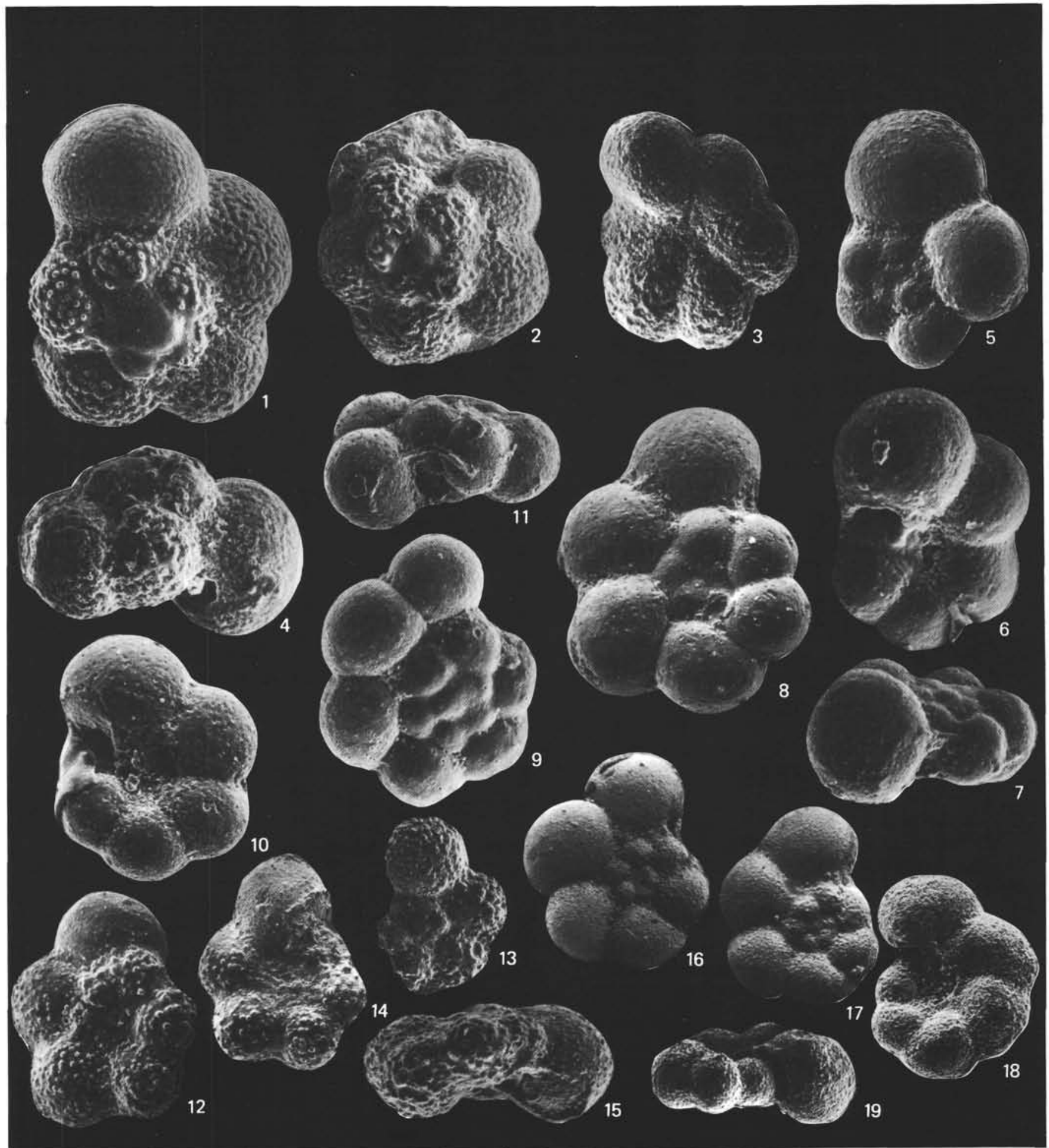

Plate 3. Cretaceous planktonic foraminifers. 1-4. Hedbergella delrioensis (Carsey), Sample 511-52-7, 14-16 cm (1-2) $\times 200$, spiral view, (3) $\times 140$, ventral view, (4) $\times 250$, peripheral view. 5-7. Hedbergella infracretacea (Glaessner), $\times 300$, Sample $511-54-4,34-36 \mathrm{~cm}$, (5) spiral view, (6) ventral view, (7) peripheral view. 8-11. Hedbergella globigerinellinoides (Subbotina), (8-9) spiral view (8, $\times 250$, Sample 511-51-1, 60-62 $\mathrm{cm} ; 9, \times 300$, Sample 511-50-4, 44-46 cm), (10-11) $\times 270$, Sample 511-50-4, 44-46 cm (10, ventral view; 11, peripheral view). 12-15. Hedbergella aff. simplicissima (Magne and Sigal), Sample 511-49-5, 120-122 cm (12-13) spiral view $(12, \times 100 ; 13, \times 120),(14) \times 100$, ventral view, (15) $\times 120$, peripheral view. 16-19. Hedbergella aff. infracretacea (Glaessner), $\times 100$, Sample $511-50-1,18-20 \mathrm{~cm}(16-17)$ spiral view, (18) ventral view, (19) peripheral view. 


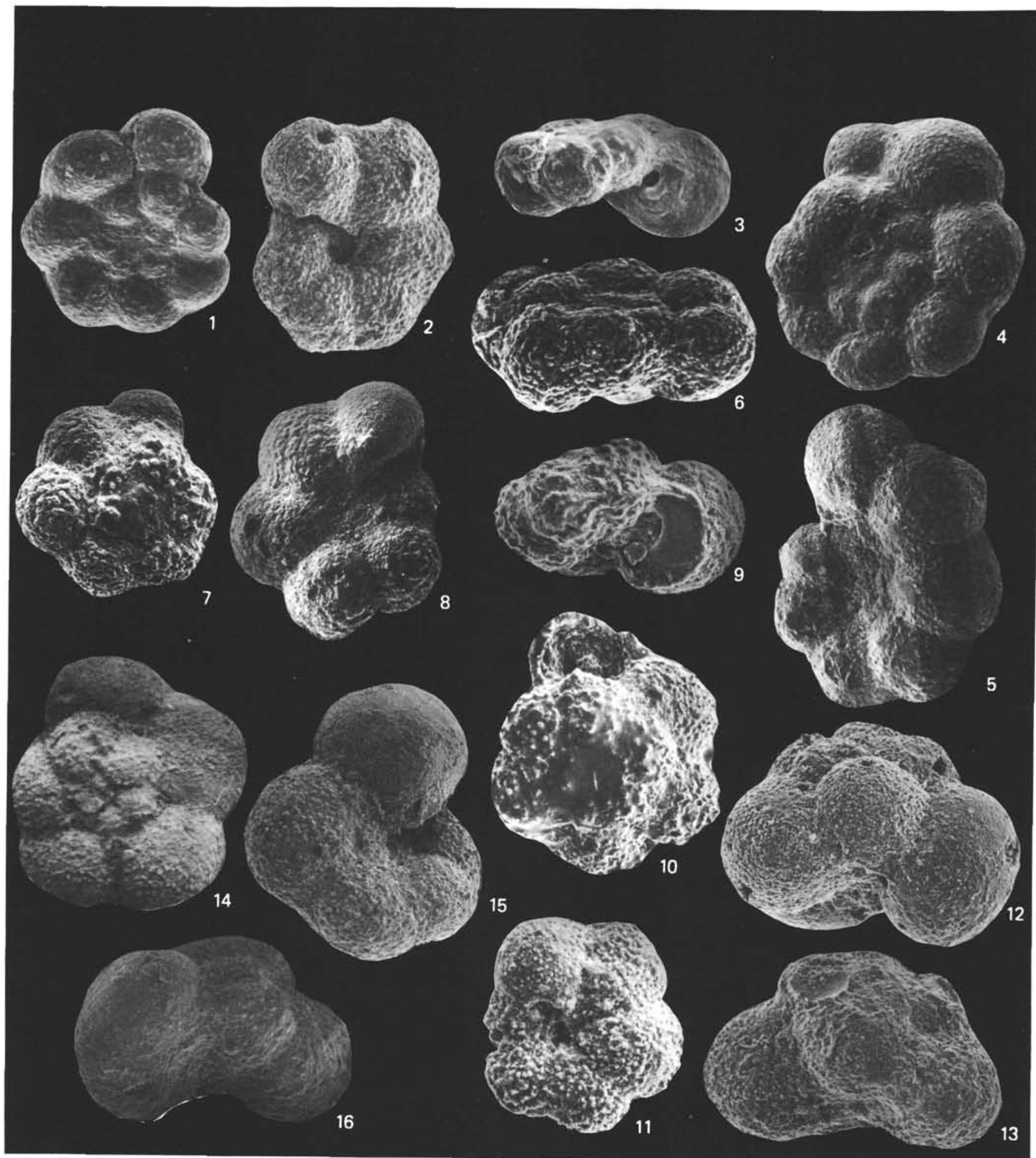

Plate 4. Cretaceous planktonic foraminifers. 1-6. Hedbergella planispira (Tappan), (1-3) $\times 260$, Sample 511-49-5, 102-104 cm (1, spiral view; 2 , ventral view; 3, peripheral view), (4-6) $\times 300$, Sample $511-50-1,18-20 \mathrm{~cm}(4$, spiral view; 5 , ventral view; 6, peripheral view). 7-9. Hedbergella trocoidea (Gandolfi), Sample 511-57-4, 44-46 cm, (7) $\times 120$, spiral view, (8-9) $\times 130$ (8, ventral view; 9 , peripheral view). $10-13$. Hedbergella brittonensis Loeblich and Tappan, Sample 511-49-5, 102-104 cm, (10) $\times 150$, spiral view, $(11) \times 130$, ventral view, (12, 13) peripheral view $(12$, $\times 150 ; 13, \times 130) .14-16$. Hedbergella portsdownensis (Williams-Mitchell), Sample 511-49-5, 102-104 cm, (14) $\times 150$, spiral view, (15-16) $\times 180$ (15, ventral view; 16 , peripheral view). 


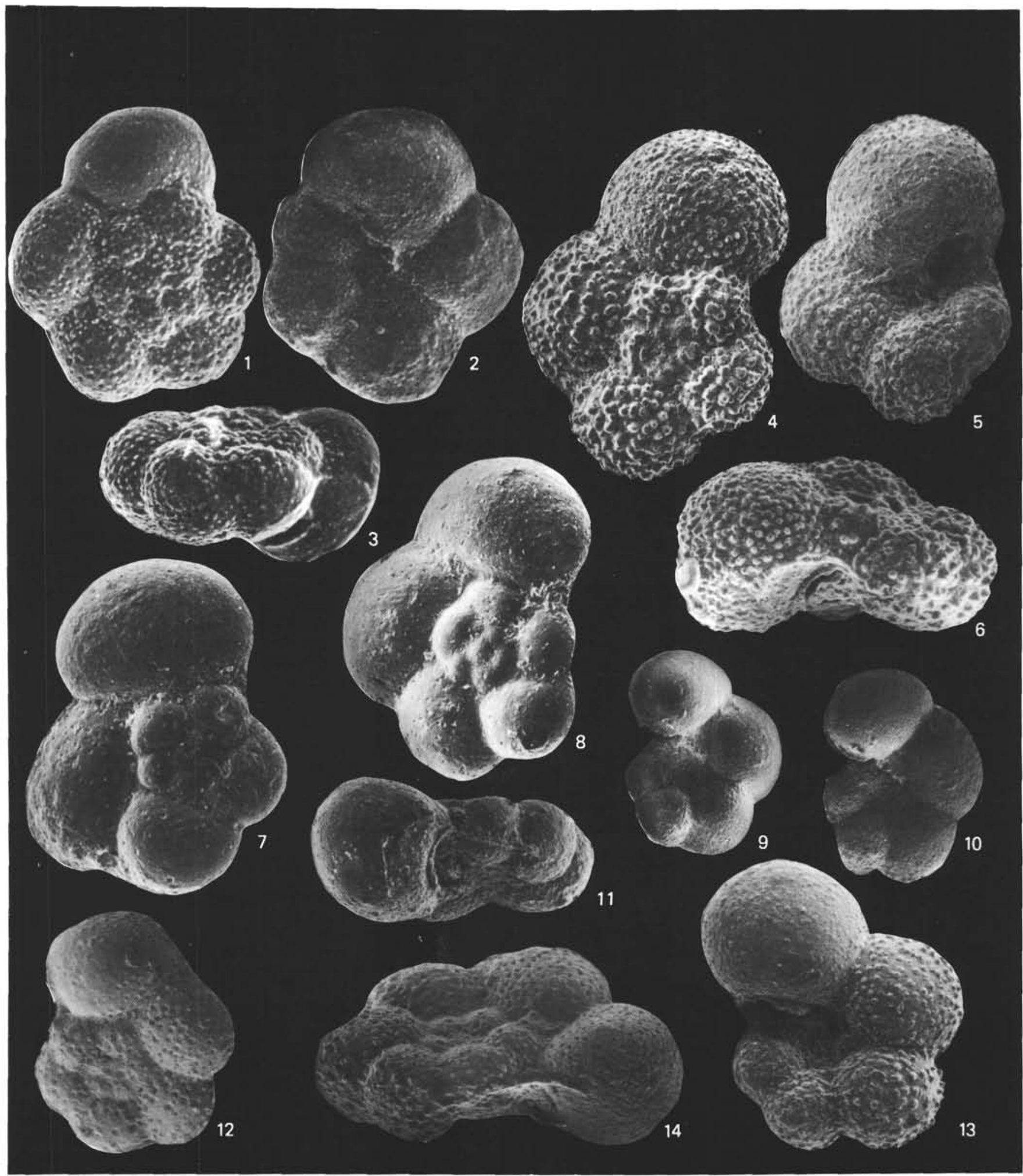

Plate 5. Cretaceous planktonic foraminifers. 1-3. Hedbergella crassa (Bolli), (1) $\times 250$, spiral view, Sample $511-41, \mathrm{CC},(2) \times 160$, ventral view, Sample 511-42,CC, (3) $\times 250$, peripheral view, Sample 511-36-3, 104-106 cm. 4-6. Hedbergella sp. 2, $\times 200$, Sample 511-48-1, 35-37 cm, (4) spiral view, (5) ventral view, (6) peripheral view. 7-11. Hedbergella sp. 1, Sample 511-52-1, 60-62 cm, (7-8) spiral view $(7, \times 220 ; 8, \times 275)$, $(9-10) \times 120$, ventral view, (11) $\times 200$, peripheral view. 12-14. Hedbergella holzli $($ Hagn and Zeil), (12-13) Sample 511-46,CC (12, $\times 160$, spiral view; $13, \times 220$, ventral view), (14) $\times 300$, peripheral view, Sample $511-45-1,98-100 \mathrm{~cm}$. 


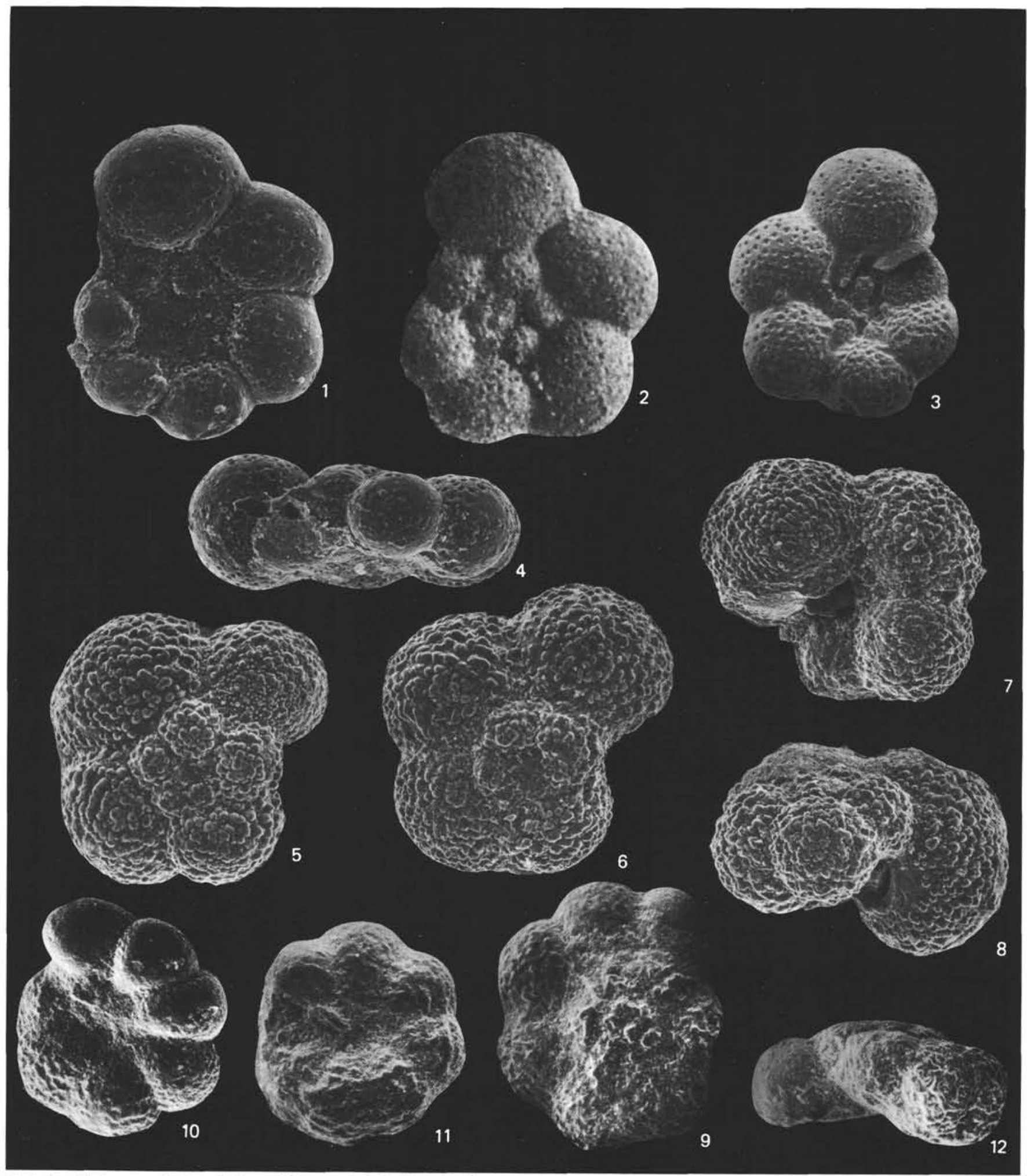

Plate 6. Cretaceous planktonic foraminifers. 1-4. Hedbergella loetterli (Nauss), (1-3) Sample 511-41,CC (1-2, $\times 200$, spiral view 3, $\times 240$, ventral view), (4) $\times 200$, peripheral view, Sample 511-36-3, 104-106 cm. 5-8. Hedbergella monmouthensis (Olsson), Sample 511-24,CC, (5-6) spiral view $(5, \times 200 ; 6, \times 180),(7) \times 180$, ventral view, $(8) \times 200$, peripheral view. 9-12. Ticinella roberti (Gandolfi), $\times 100$, Sample 511-56-1, $119-121 \mathrm{~cm}$, (9) spiral view, (10-11) ventral view, (12) peripheral view. 


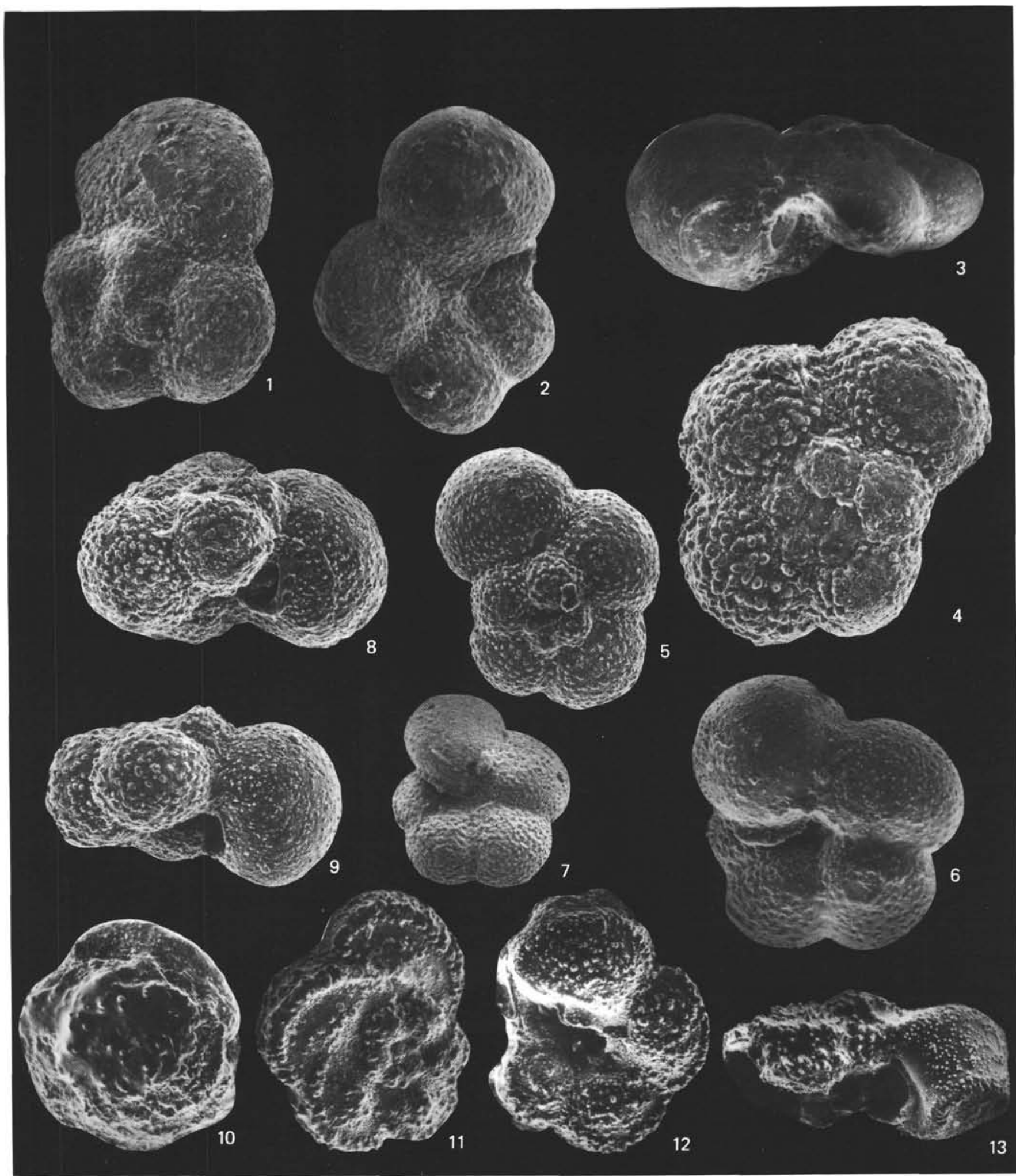

Plate 7. Cretaceous planktonic foraminifers. 1-3. Globotruncanella inornata (Bolli), Sample 511-47-4, $44-46 \mathrm{~cm},(1-2) \times 200$ (1) spiral view; 2 , ventral view), (3) $\times 260$, peripheral view. 4-9. Whiteinella baltica Douglas and Rankin, (4-5) spiral view (4, $\times 200$, Sample 511-36-6, 128-130 $\mathrm{cm} ; 5, \times 180$, Sample 511-43,CC), (6-7) $\times 200$, ventral view, Sample 511-41,CC, (8-9) peripheral view $(8, \times 250$, Sample 511-36-6, 128-130 cm; 9, $\times 200$, Sample 511-43,CC. 10. Praeglobotruncana turbinata (Reichel), $\times 100$, spiral view, Sample 511-49-5, 102-104 cm. 11-13. Globotruncana plummerae Gandolfi, $\times 120$, Sample 511-42,CC, (11) spiral view, (12) ventral view, (13) peripheral view. 

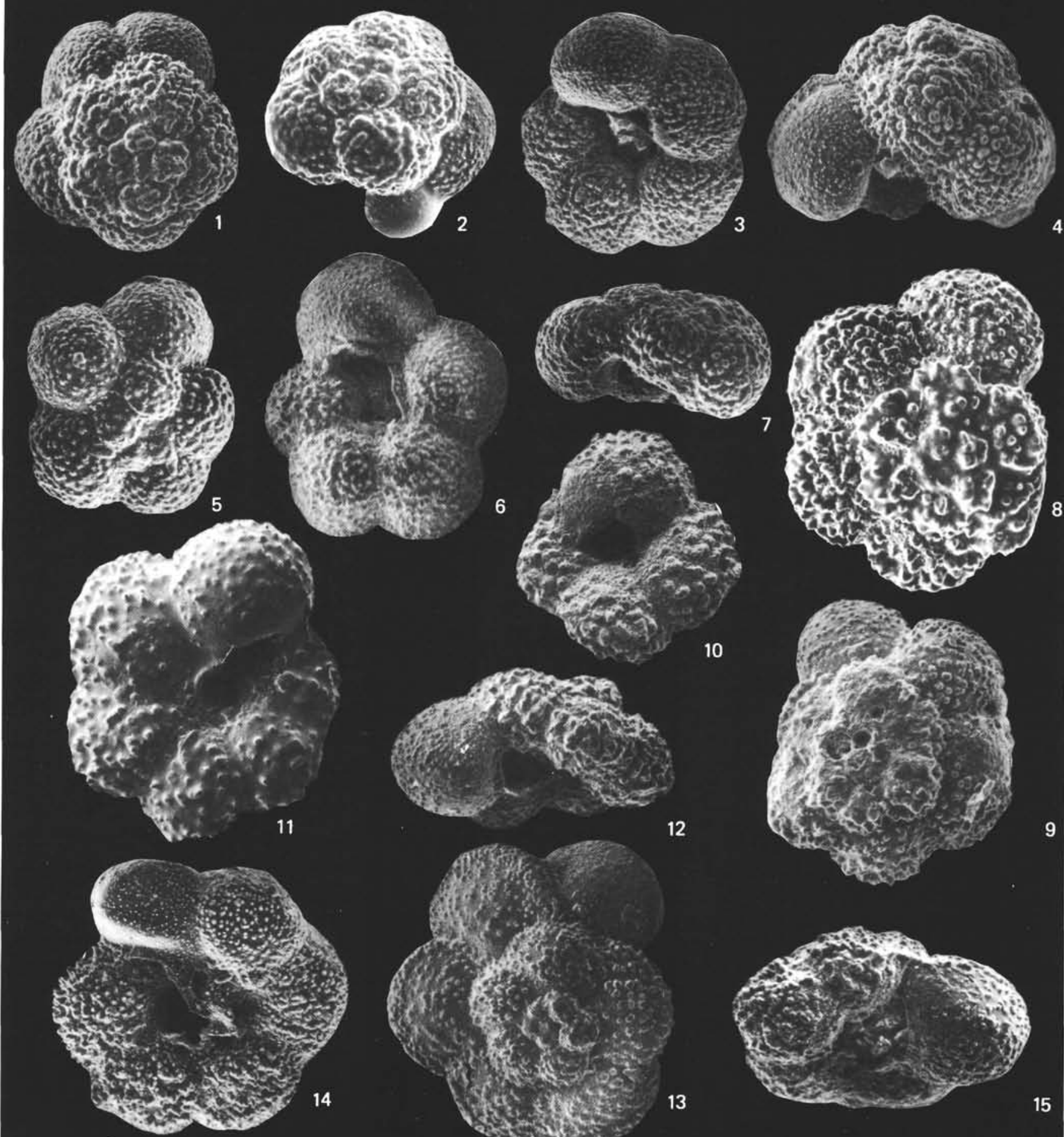

10
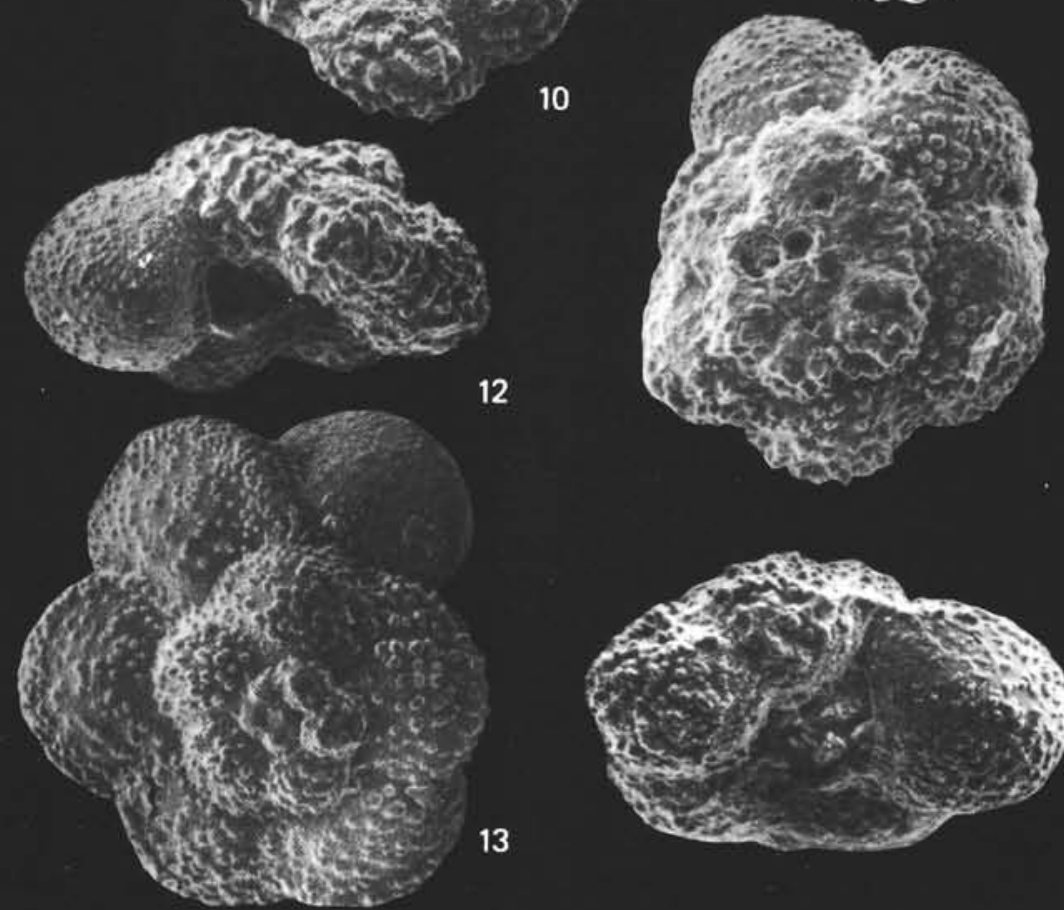

12

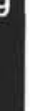

Plate 8. Cretaceous planktonic foraminifers. 1-4. Archaeoglobigerina bosquensis Pessagno, high conical form, Sample 511-42,CC, (1-2) $\times 100$, spiral view, (3-4) $\times 120$ (3, ventral view; 4, peripheral view). 5-7. Archaeoglobigerina bosquensis Pessagno, low conical form, (5) $\times 120$, spiral view, Sample 511-46,CC, (6) $\times 150$, ventral view, Sample 511-42,CC, (7) $\times 120$, peripheral view, Sample 511-45-1, 98-100 cm. 8-12. Praeglobotruncana aff. oraviensis Scheibnerová, (8-9) spiral view, Sample 511-48-1, 35-37 cm $(8, \times 120 ; 9, \times 100)(10-11)$ ventral view, Sample $511-48-1,18-20 \mathrm{~cm}(10, \times 100 ; 11, \times 120)(12) \times 100$, peripheral view, Sample $511-48-1,35-37 \mathrm{~cm} .13-15$. Globotruncana cretacea (d’Orbigny), (13-14) Sample 511-34,CC (13, $\times 100$, spiral view; 14, $\times 120$, ventral view), $(15) \times 120$, peripheral view, Sample 511-34-5, 46-48 $\mathrm{cm}$. 


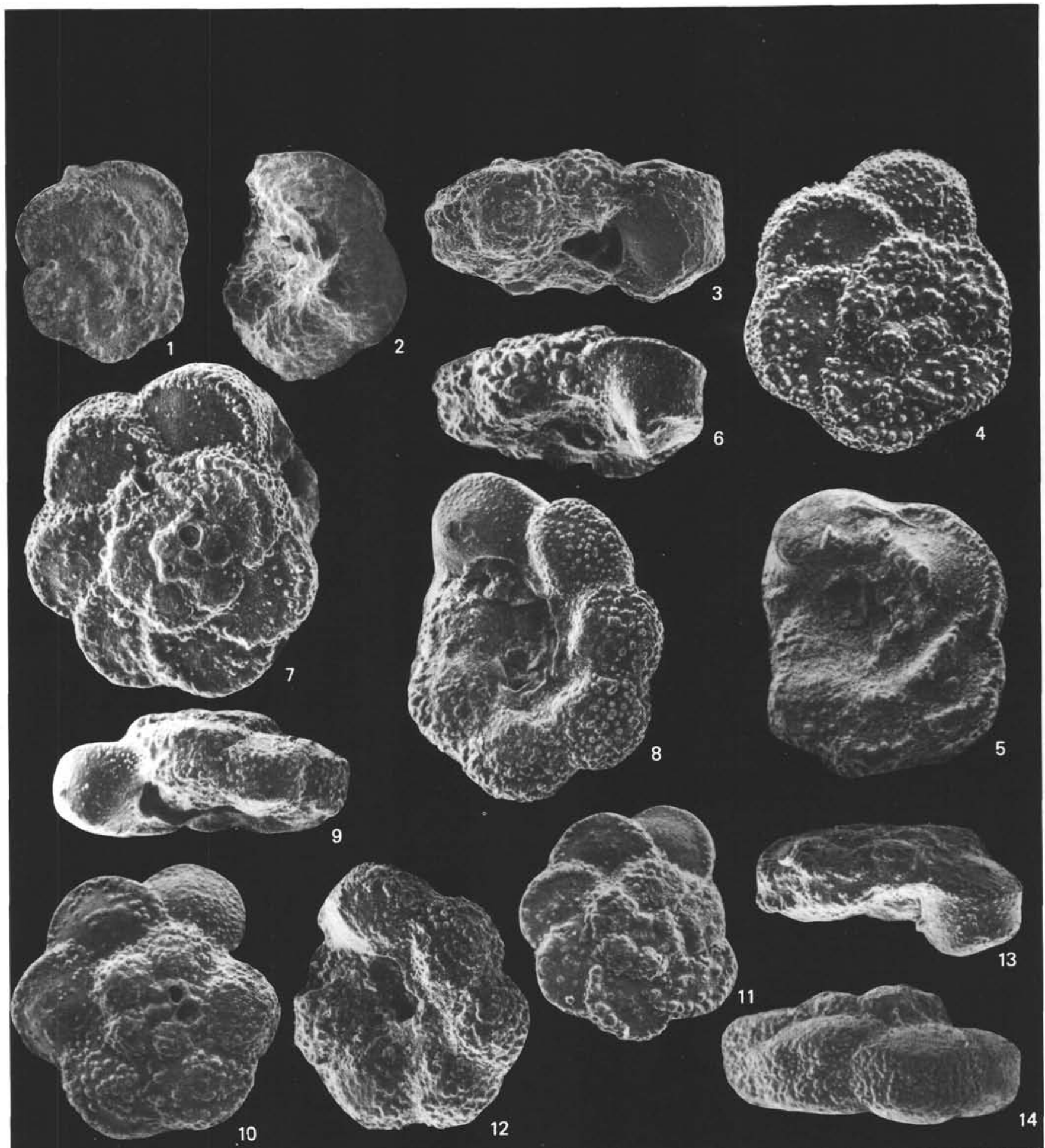

Plate 9. Cretaceous planktonic foraminifers. 1-3. Globotruncana pseudolinneiana Pessagno, (1) $\times 100$, spiral view, Sample 511-41,CC, (2) $\times 100$, ventral view, Sample 511-47,CC, (3) $\times 150$, peripheral view, Sample 511-41,CC. 4-6. Globotruncana linneiana (d'Orbigny), (4-5) Sample 511-33-4, 122-124 cm (4, $\times 100$, spiral view; 5, $\times 140$, ventral view), (6) $\times 150$, peripheral view, Sample 511-36-1, 70-72 cm. 7-9. Globotruncana coronata Bolli, (7-8) $\times 160$, Sample 511-35-2, 70-72 cm, (7, spiral view; 8, ventral view), (9) $\times 150$, peripheral view, Sample 511-35-2, $70-72 \mathrm{~cm} . \quad 10-14$. Globotruncana marginata (Reuss), (10-12) $\times 90$, Sample 511-36-1, 70-72 cm (10-11, spiral view; 12, ventral view) (13-14) peripheral view, Sample 511-36-3, 104-106 cm $(13, \times 90 ; 14, \times 100)$. 


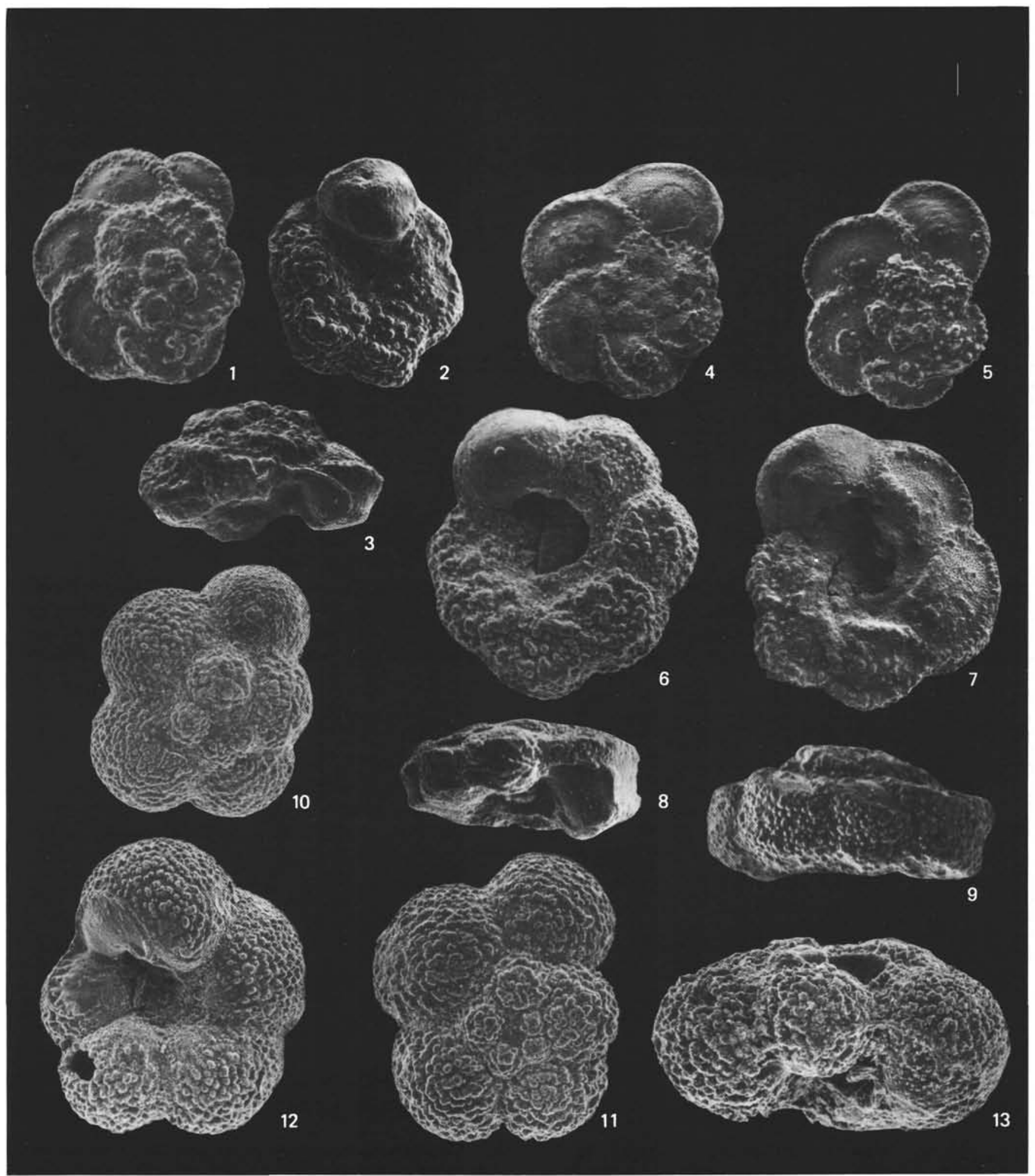

Plate 10. Cretaceous planktonic foraminifers. 1-3. Globotruncana arca (Cushman), $\times 100$, (1) spiral view, Sample 511-41-3, 55-57 cm, (2-3) Sample 511-42,CC (2, ventral view; 3, peripheral view). 4-9. Globotruncana bulloides Vogler, (4-6) $\times 120$, Sample 511-36-1, 70-72 cm (4-5, dorsal view; 6, ventral view) (7-9) Sample 511-42,CC (7, ×120, ventral view; 8, ×140, peripheral view; 9, $\times 120$, peripheral view). 10-13. Rugoglobigerina pustulata Brönnimann, Sample 511-24,CC (10-11) $\times 140$, spiral view (12) $\times 150$, ventral view, (13) $\times 180$, peripheral view. 


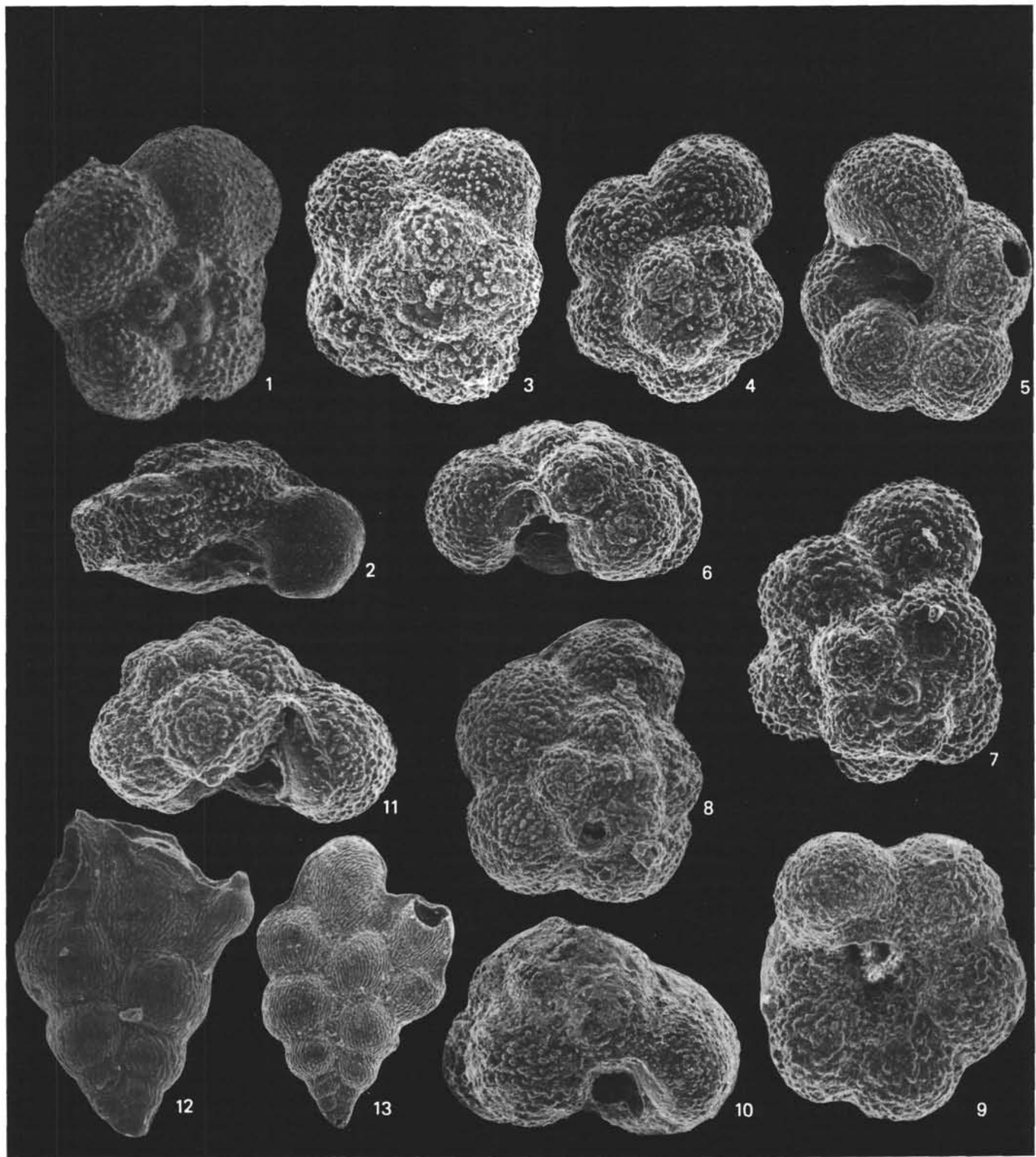

Plate 11. Cretaceous planktonic foraminifers. 1-2. Globotruncana globigerinoides Brotzen, $(1) \times 200$, spiral view, Sample 511-35-2, 70-72 cm, (2) $\times 120$, peripheral view, Sample 511-34-5, 46-48 cm. 3-6. Rugoglobigerina pilula Belford, $\times 140$, Sample 511-24,CC, (3-4) spiral view, (5) ventral view, (6) peripheral view. 7-11. Rugoglobigerina rotundata Brönnimann, (7-9) Sample 511-24-5, 78-80 cm (7, $\times 150$, spiral view; 8, $\times 140$, spiral view; $9, \times 170$, ventral view) $(10-11) \times 150$, peripheral view, Sample $511-24-5,78-80 \mathrm{~cm}$. (12-13) Planoglobulina carseyae (Plummer), side view, Sample $511-24-3,78-80 \mathrm{~cm}(12, \times 140,13, \times 110)$. 


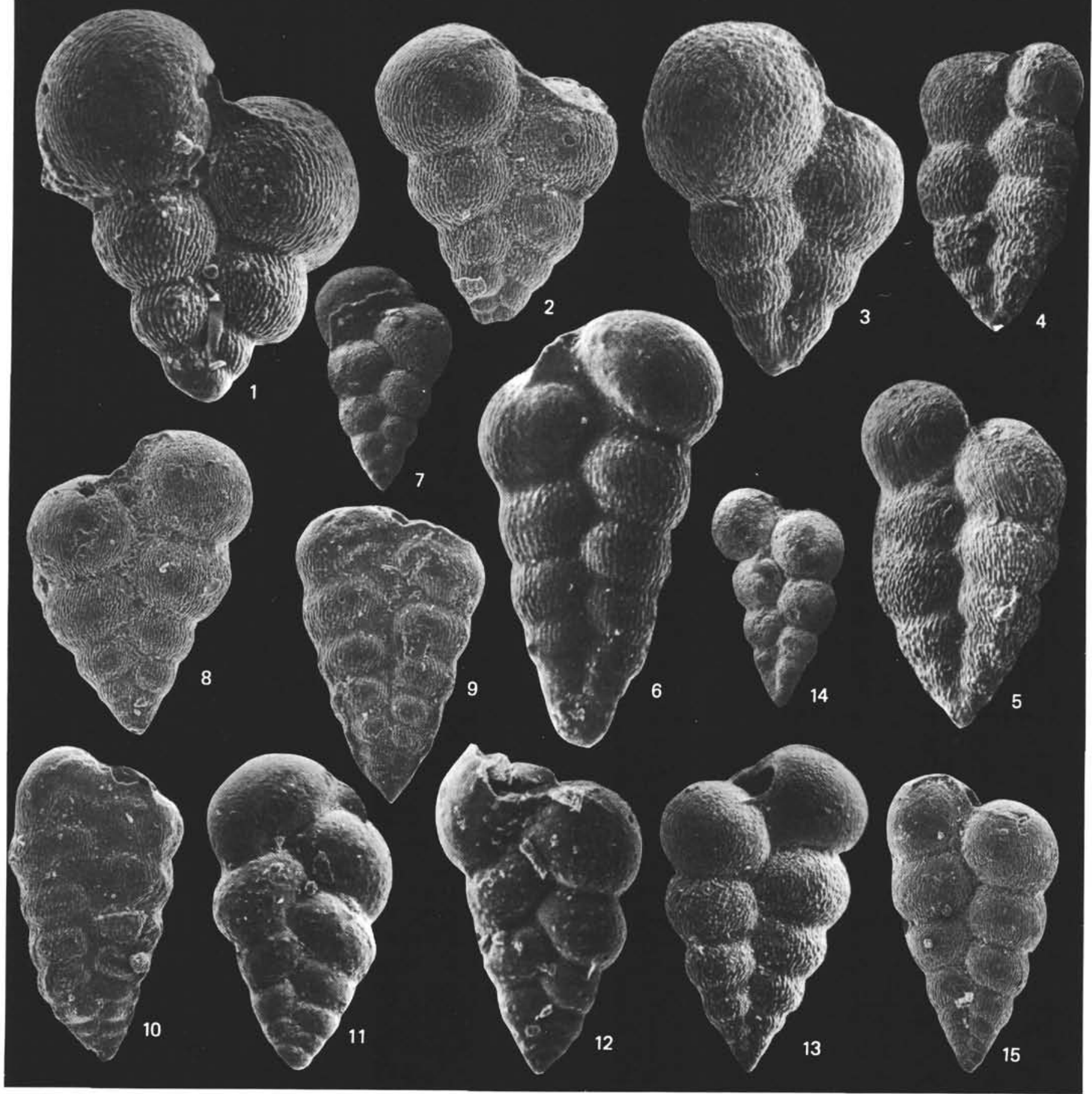

Plate 12. Cretaceous planktonic foraminifers. 1-3. Heterohelix reussi (Cushman), side view, $(1) \times 200$, Sample $511-45-1,98-100 \mathrm{~cm},(2) \times 140$, Sample 511-24-5, 78-80 cm, (3) $\times 170$, Sample 511-45-1, 98-100 cm. 4-5. Heterohelix rumseyensis Douglas, side view, Sample 511-36-1, 70-72 $\mathrm{cm}(4, \times 140 ; 5, \times 130)$. 6-8. Heterohelix pulchra (Brotzen), side view, $(6-7)$ Sample $511-45-1,98-100 \mathrm{~cm}(6, \times 300 ; 7, \times 130),(8) \times 200$, Sample 511-24-3, 78-80 cm. 9-10. Heterohelix glabrans (Cushman), side view, Sample $511-24-4,78-80 \mathrm{~cm},(9, \times 140 ; 10, \times 130)$. $11-12$. Heterohelix sp. 1, side view, Sample 511-36-1, 70-72 cm, (11) $\times 250,(12) \times 270$. 13-15. Heterohelix globulosa (Ehrenberg), side view, (13-14) Sample $511-45-1,98-100 \mathrm{~cm}(13, \times 100 ; 14, \times 110),(15) \times 100$, Sample $511-24-4,78-80 \mathrm{~cm}$. 